\title{
The opinions of school principals on decentralization in education
}

\author{
Ahmet Şahin \\ Alanya Alaaddin Keykubat University, Faculty of Education, Alanya, Turkey, \\ ahmet.sahin@alanya.edu.tr, orcid.org/0000-0002-1254-393X
}

\begin{abstract}
The study aims to determine the opinions of school principals on decentralization in education. Phenomenological research design was used in the study. The purposive sampling methods of convenience and criterion samplings were used together. The study group was composed of six volunteer principals. The data were collected through individual face-to-face interviews using a semi-structured form. Descriptive analysis and inductive content analysis were used. In conclusion, from a holistic perspective, most of the participants found the concept of decentralization to be close to full autonomy which is usually perceived as dangerous in terms of the unitary state structure. Therefore, they have more centralized attitudes towards educational processes other than financing and infrastructure support regarding decentralization in education. This is indeed an indication that concerns regarding decentralization in education are high. The participants think that decentralization will not harm our national identity and the national education structure is beneficial.
\end{abstract}

Keywords Decentralization in education, School principal, Deconcentration, Delegation, Devolution,

\section{Eğitimde yerelleşmeye ilişkin okul müdürlerinin görüşleri}

ÖZ Çalışmanın amacı, okul müdürlerinin eğimde yerelleşmeye ilişkin görüşlerinin belirlenmesidir. Çalışmada olgu bilim deseni kullanmıştır. Çalışma grubunun belirlenmesinde amaçlı örnekleme yöntemlerinden ölçüt örnekleme ve kolay ulaşılabilir durum örneklemesi birlikte kullanılmış olup altı okul müdürü çalışma grubuna alınmıştır. Veriler yarı-yapılandırılmış görüşme formunun kullanıldığı bireysel yüz yüze görüşmelerle toplanmıştır. Analiz sürecinde betimsel analiz ve tümevarımsal içerik analizi yapılmıştır. Sonuç olarak yerelleşme kavramına ilişkin görüşlere bütünsel açıdan bakıldığında katılımcıların çoğunluğunun yerelleşmeyi tam özerkliğe yakın buldukları görülmektedir. Bu durum ise üniter devlet yapısı açısından tehlikeli görülmektedir. $\mathrm{Bu}$ nedenle, eğitimde yerelleşmeye ilişkin görüşleri sorulduğunda katılımcıların eğitim sisteminin yerelleşmesine ilişkin finansman ve altyapı desteği dışında daha merkeziyetçi tutum sergiledikleri görülmektedir. Bu durum aslında eğitimde yerelleşmeye ilişkin kaygıların yüksek olduğunun bir göstergesidir. Katılımcılarda ulus devlet kimliğimize ve eğitimin milli yapısına zarar vermeyecek bir yerelleşme anlayışının hâkim olduğu söylenebilir.

Eğitimde yerelleşme, Okul müdürü, Görevlendirme, Yetki aktarma, Yetki devretme,

Cite This Şahin, A. (2018). The opinions of school principals on decentralization in education. Turkish Article: Journal of Education, 7(2), 55-85. DOI: 10.19128/turje.345444 


\section{INTRODUCTION}

Decentralization is defined as the delegation of existent authority over certain issues and situations to lower local units. At the same time, decentralization refers to the delegation of the authority to make decisions and the tasks themselves to those who actually do it. In other words, it is the delegation of the authority and responsibilities with regards to public activities of the centralized government to the provincial organizations, local governments, semi-autonomous public institutions or private sector (Atasayar, 2005; Balc1, 2010; Litvack \& Seddon, 1999; Özmüş, 2005; Sağlam, 2010; Uz, 2009; Yuliani, 2004). Central government transfers its responsibility and authority to sub-national units in decentralization (The World Bank, 2013).

There are different decentralization models and styles due to the variety of perspectives regarding localization and the meanings they give it. Litvack and Seddon (1999) distinguished between decentralization as political, administrative, financial, and market decentralization. Based on the type of authority devolved, Falleti (2005) similarly, distinguished three types of decentralization: administrative, fiscal, and political decentralization. Administratively, decentralization is considered to be deconcentration, delegation and devolution. Similarly, a distinction is made between the forms of decentralization and the degree of decentralization. Accordingly, decentralization has been divided into three different styles, e.g., deconcentration, delegation and devolution (Arslan \& Atasayar, 2008; Florestal \& Cooper, 1997; Hanson, 1998; Koçak-Usluel, 1997; Ömür, 2017; Özdemir, 2008; Schneider, 2003; The World Bank, 2013; Yuliani, 2004). Some divide it into four different categories by adding privatization: (1) Deconcentration, (2) Delegation, (3) Devolution, and (4) Privatization (Balc1, 2010; Dubois \& Fattore, 2009; Florestal \& Cooper, 1997; Özmüş, 2005; Rondinelli, Nellis \& Cheema, 1983; Sağlam, 2010; Sharma, 2006).

Deconcentration is a shifting of the workload to the offices outside the central government. Central government establishes field organizations and staff them with its own personnel. In doing so, centrally located officials hand over some of their administrative authority or responsibility to the lower levels within central government. That is, deconcentration is the carrying out of a number of bureaucratic tasks through the provincial organizations (outlying field organizations of central government). Delegating political authority is not what is being talked about here. It is the transfer of administrative authority to the lower levels of administration. For this reason, the deconcentration is considered to be the lightest form of decentralization (Balc1, 2010; Duman, 1998; Koçak-Usluel, 1997; Mukundan \& Bray, 2004; Özmüş, 2005; Rondinelli, Nellis \& Cheema, 1983; Satria \& Matsuda, 2004; Yolcu, 2010; Yuliani, 2004).

Delegation can be defined as the transfer of centralized administrative tasks to autonomous organizations. Because it is the process of delegating tasks, delegation is a higher-level form of decentralization. With delegation, centralized administrations will transfer decision-making and responsibility powers to semi-autonomous institutions. These institutions cannot be fully controlled, but rather indirectly supervised by the central government. In delegation model, all authorities and tasks are transferred to local organizations in order to fulfill their defined functions provided that ultimate responsibility remains with the central government (Balc1, 2010; Florestal \& Cooper, 1997; KoçakUsluel, 1997; Mukundan \& Bray, 2004; Özmüş, 2005; Rondinelli, Nellis \& Cheema, 1983; Satria \& Matsuda, 2004).

Devolution refers to the vacating of authority by the central government and provincial organizations to the local governments. It is the establishment of sub-national units that are autonomous and independent through the transfer of authority, with the authority to collect and spend income. It is apparent that power has been transferred to local governments. In the transfer of authority, decision-making authority is shared between the central and local governments. It is a form of decentralization, which entails the transfer of authority from the provincial organizations to the local government. In other words, it creates an autonomous lower-level structure under the national structure. In this localized form, the local government is free in many ways. The geographical boundaries of the regions are well drawn, their legal status is clearly defined, and they are in a position to generate income and to spend it. The difference between devolution and delegation is that it is not just a delegation of the administrative function but rather at the same time is the transfer of authority and responsibility. However, even then, it does not provide a structure that is completely autonomous (Balc1, 2010; Barrera-Osorio, Fasih, Patrinos, \& Santibáñez, 2009; Florestal \& Cooper, 1997; Hanson, 1998; Koçak-Usluel, 1997; Özmüş, 2005; 
Sharma, 2006; Yuliani, 2004). In summary, devolution is the creation or strengthening of subnational units of government that are autonomous and independent financially or legally (Rondinelli, Nellis \& Cheema, 1983).

Privatization refers to the transfer of duties in various capacities of the central government to voluntary, for-profit or non-profit private organizations. Privatization is the ultimate form of decentralization and aims to give decision-making authority to companies in the public or the private sector (Balc1, 2010; Florestal \& Cooper, 1997; Özmüş, 2005).

Turkish education system has a centralized model run by central government (Erdem, 2016; Kurt, 2006; Papadopoulou and Yirci, 2013). Ministry of National Education represents the central government and run the educational services on behalf of it. Central organization of the ministry has been organized within the framework of deconcentration in which centrally located officials hand over some of their administrative authority or responsibility to the lower levels (Erdem, 2016). As in most of the countries, there are different types of schools run by public and private sectors in Turkey. Although, both public and private schools are under the authority of the ministry, private schools are more autonomous on several tasks such as administration, planning, employment, student enrollment, and budgeting. However, private schools are also subject to the same rules as public schools in the areas of curriculum, examinations, certification, and inspection (Erdem, 2016; Milli Eğitim Bakanlığı, 2011; Memduhoğlu, 2013; Papadopoulou \& Yirci, 2013).

As for the opinions regarding decentralization, there appears to be differences in the literature. Along with the ideas that decentralization in education is beneficial and effective as it can determine and fulfill local needs better, that it will provide a better way to use available resources (Özgen, 2011; Taşç1, 2008; Yolcu, 2010), that it will increase service quality, speed, and performance (Arslan \& Atasayar, 2008; Balc1 Bucak, 2000; Geçit, 2008; Özgen, 2011; Sağlam, 2010; World Development Report [WDR], 2017), that it will bring the government and the public closer together (Balc1 Bucak, 2000; Faguet, Fox \& Poeschl, 2014; Güran, 2001), that it will increase both participation and contribution of the community (Kurt, 2006), and that it can adapt to change quicker (WDR, 2017). There are also some negative opinions of decentralization. Özgen (2011) states that financial inequalities, together with decentralization will lead to differences in service quality between local governments. Likewise, Prud'homme (1995) argues that decentralization can increase disparities. Arslan and Atasayar (2008), Balcı Bucak (2000), and Taşçı (2008) argue that local political pressure upon public service production will increase, as well as inefficiency and favoritism due to bureaucracy and personnel recruiting. Hanson (1998), and Taşçı (2008) claim that decentralization of education can distance the curricula from the national structure. In this regard, it can be said that decentralization of education will not be able to provide equality and a standard of quality throughout the country (Balc1 Bucak, 2000; Geçit, 2008; Sağlam, 2010; Taşar, 2009). Moreover, it will be difficult to follow a single policy and coordination between local governments will become more difficult (Balc1 Bucak, 2000; Sağlam, 2010). It is also voiced that since the local governments have put the regions at the forefront, the national state structure may deteriorate (Taşç1, 2008). It is also claimed that since the local governments have put the regions at the forefront, the national state structure may deteriorate (Taşçı, 2008). Similarly, Ökmen and Canan (2009) hold the view that ethnic and cultural characteristics are emphasized for the purpose of decentralization in underdeveloped societies so that they can be disintegrated politically and dominated by global powers. In this way, global powers will be able to navigate underdeveloped societies more easily and thus international capital will be able to move freely.

When literature on decentralization in education is examined, it is seen that many studies have been made regarding the decentralization of the Turkish education system. The debates on the education system in Turkey are focused densely on excessive centralization and over-growth of the central organization (Kurt, 2006). Therefore, it is seen that many topics have already been discussed regarding decentralization in education such as the views of authorities in the education system regarding who should be found in the hierarchical structure (Arslan \& Atasayar, 2008; Bozan, 2002; Koçak-Usluel, 1997), the provincial school administrators' views regarding the decentralization of education (Kiran, 2001; Yavuz, 2001), the opinions of teachers regarding the school-based management system (Kaya, 2008), the negative effects central government has upon schools, (Taşar, 2009), the historical timeline of decentralization in education (Özdemir, 2008), the role and effects of local governments on education expenditures (Uzun, 2015) and the autonomy of schools (Göksoy, 2016). These studies are actually 
usually about who or which unit should be the authorities in the hierarchical structure. They try to determine the superficial views regarding decentralization of education.

As for this study, principals' attitudes towards decentralization in education both in the context of their expectations as well as their concerns have been examined and, in terms of educational processes, decentralization models projected to the end have been determined both separately and at a holistic level. Therefore, the study analyses the educational processes according to different decentralization models regarding the views of school principals, and suggests which level of decentralization model is best for various processes in education. It also recommends a holistic model for the whole education system. In this regard, the study contributes to systematic design both for policy makers and practitioners in the context of the fact that decentralization implementation in education can be adopted. Since, we need to take the concerns, expectations and suggestions of stakeholders into consideration in order to design a decentralization model which enhances the education system. However, the success and applicability of decentralization efforts seem mostly dependent upon policy makers and practitioners. Central government and policy makers should hear the voices of practitioners in order to improve the system. The quality is hidden in feedback, which means hearing the voices of employees. Since the school principals' views on decentralization efforts are significant, this study is, first, a kind of feedback on decentralization of education for central government. Second, it is an effective guide for policy makers to design a well-functioning education system, which fulfills local needs, uses resources well, delivers quality services and adapts to change quicker. The study, finally, tries to uncover different perspectives on decentralization of education that will provide some insights on what researchers can study.

The acceptance of the necessity of the local government principle for sustainable development does not necessarily mean that the state structure will change. The important thing is that the management structure is kept in view. In this sense, management practices can be accomplished successfully in the nation-state structure (Mengi \& Algan, 2003). Decentralization of education may also be an important tool to provide effectiveness and productivity in educational services if it is designed and implemented in an appropriate way according to the state structure and the society. Thus, the aim of the study is to determine the opinions of school principals in context of their anxiety, expectation and recommendations regarding decentralization in education.

\section{METHODOLGY}

\section{Research Design}

In this study, which aims to determine in depth the opinions of school principals regarding decentralization in education, the phenomenological research design, one of the qualitative research methods, was used. Phenomenological studies attempt to determine in depth and detail the perceptions and reactions of an event from the experience of individuals (Fraenkel, Wallen \& Hyun, 2011). Thus, in phenomenological studies, the researcher attempts to capture the uniqueness of events from the interpretive point of view and their analysis. Therefore, not only the events but also the political, historical and sociocultural context of these events are also focused on (Yin, 2011). In other words, the researcher focuses on phenomena in which s/he has knowledge of and is conscious of but does not have an in-depth and detailed understanding of (Büyüköztürk, Çakmak, Akgün, Karadeniz \& Demirel, 2010; Yıldırım \& Şimşek, 2011) and aims to discover and define the meaning or essence of the participants' knowledge and experience. In short, the researcher tries to understand his/her experiences (Creswell, 2014; Hays \& Singh, 2012). In this sense, the phenomenological research design was used in the study in order to discover in depth the perceptions and reactions of school principals about decentralization in education.

\section{Study Group}

In phenomenological studies, data sources are chosen from individuals who experience the related subject and who can express and reflect their thoughts well (Büyüköztürk, Çakmak, Akgün, Karadeniz \& Demirel, 2010). The study used the purposive sampling methods of convenience and criterion samplings together in accordance with the design of the study (Yıldırım \& Şimşek, 2011). Volunteer principals who have worked in public schools, trained in education management, have administrative experience at both primary and lower secondary school levels for at least five years were preferred during the selection of the participants. It was assumed that principals who have had either long or short 
training in educational management would be more familiar with administrative approaches and thus would be able to provide a deeper understanding of decentralization in education. Therefore, the study group consists of six school principals, working in primary or lower secondary schools in central districts of Antalya Province. The principals were carefully chosen so that the schools they were working in reflect the different socio-economic milieu. In Turkish education system, the percentage of female school principals is very low (The female school principal rate for primary education schools in the province of Antalya is 10.9\%; Milli Ĕgitim Bakanliğl [MEB], 2015) making it difficult to reach female principals. Available female principals refrained from participating in the study because they were hesitant to talk about the concept of decentralization. For this reason, all of the principals who participated in the study were male. When the teaching subjects of the participants were examined, it was observed that $4(66.4 \%)$ were classroom teachers, $1(16.7 \%)$ was a mathematics teacher, and 1 $(16.7 \%)$ was a social studies teacher. One $(16.7 \%)$ participant has a master's degree on social studies education while the other $5(83.3 \%)$ participants have a bachelor's degree. All participants attended inservice administrator training courses on education management offered by Ministry of National Education of Turkey. Participants' service time in administration (STinA) ranged from 7 to 15 years $\left(\mathrm{STinA}_{\text {mean }}=10.7\right.$ years$) ;$ total service time $(\mathrm{TST})$ ranged from $14-25$ years $\left(\mathrm{TST}_{\text {mean }}=18.3\right.$ years $)$.

\section{Data Collection Tool and Data Collection Process}

In the study, individual face-to-face interviews were conducted in the offices of the school principals who participated in the study. Yıldırım and Şimşek (2011) point out that interviewing, which is one of the qualitative methods, is a very powerful way of determining the perspectives, emotions and perceptions of people. The interviews lasted approximately for 68 minutes. A semi-structured interview form prepared by the researcher was used as the data collection tool in the interviews. In order to ensure internal validity of the interview form, the interview form was examined together with an academician and a principal and the final form was prepared according to that. The researcher recorded the interviews by using a voice recorder and then the voice recordings were transcribed.

The first part of the interview form contains demographic information of the participants and the second part contains four semi-structured, open-ended questions:

\section{What does decentralization mean? \\ What do you think about decentralization in education? \\ What needs to be done in Turkey for decentralization in education to be beneficial? \\ Which decentralization model in education is appropriate for Turkey? Why?}

In the first three questions of the second section, the principals' thoughts regarding decentralization in education were determined without any prior information. Before moving on to the fourth question, participants were informed about the various decentralization models in education and asked to reevaluate the thoughts which they had expressed in the first three questions in the context of the decentralization models given for the fourth question. In effect, the fourth question wanted school principals to model their multidimensional views regarding decentralization in education.

\section{Data Analysis}

Regarding the analysis of the data, both descriptive analysis and inductive content analysis were performed by using the NVIVO qualitative research program. As for the descriptive analysis process, a thematic framework was established with the conceptual structure of the research and the research questions, which were both regarded to be a roadmap and framework. According to this thematic framework, the data was compiled meaningfully and logically. Then, the derivation was coded using inductive content analysis and the final themes were derived by determining the relations between the codes and the findings. The aim was to reveal the concepts underlying the data and the relationships between these concepts. In addition, descriptive direct citations have been included to conspicuously reflect the views of those involved in the study (Yıldırım \& Şimşek, 2011). Finally, principals' opinions were coded as P1, P2, etc. to preserve their anonymity. 


\section{Validity and Reliability}

A thematic framework, containing criteria of analysis, has been used to provide consistency and cohesion in the analysis of qualitative data. The data was analyzed using the NVIVO qualitative research program in accordance with this framework plan. This process, which was carried out during the analysis stage, was important both in terms of the validity and the reliability of the qualitative data. Because of the consistency of the analyses made by the researcher at different times, the framework plan criterion was influential.

As a result of the analysis the researcher made, it was observed that 223 perspectives were gathered under 112 different codes. The coding and the thematic process were shared with an expert in the field of educational management. This was completed within about three and a half hours over the course of two days. A consensus was reached that 93 of the 112 codes $(83 \%)$ reflected the opinions of the researcher and expert. The researcher and expert came to an agreement and made necessary changes regarding 6 codes $(5,4 \%)$. Regarding the other 13 codes, no consensus was reached $(11.6 \%)$. Coming to a consensus regarding a large portion of the resulting codes and themes $(88.4 \%)$ increases the reliability of the study (Güler, Halıcıoğlu \& Taşğın, 2013; Marques \& McCall, 2005). The research findings were then shared with two participants, and they were asked to read and confirm whether the findings correctly reflected their perspectives. Participants' views on the findings were found to be consistent with the results of the research. This is accepted as contributing to the study's internal validity. The involvement of participants with different demographic characteristics and their consistency with each other also increases the external validity of the study. Furthermore, the integrity of the study increases as a result of its clear process, archiving of raw data, and accountability when deemed necessary (Creswell, 2014; Yıldırım \& Şimşek, 2011).

\section{FINDINGS}

In order for them to be easily understood, the results have been categorized systematically under four different headings: (1) opinions regarding the concept of decentralization, (2) opinions regarding the application of decentralization in education, (3) opinions regarding how decentralization in education would be beneficial if certain conditions were met or something was done in Turkey and (4) opinions regarding decentralization models.

\section{The meaning attributed to decentralization}

In this part, the meanings attributed to the concept of decentralization by the school principals were investigated. The phenomenological views of the principals regarding decentralization are presented in Table 1.

Table 1

Opinions Regarding the Concept of Decentralization

\begin{tabular}{|c|c|c|c|c|c|c|}
\hline Opinions & $\mathrm{P} 1$ & $\mathrm{P} 2$ & P3 & P4 & P5 & P6 \\
\hline Devolution & & $\checkmark$ & & $\checkmark$ & $\checkmark$ & \\
\hline Administrative and Economic Support of Schools with Local Resources & $\checkmark$ & & & & & \\
\hline Delegation to Local Authorities & & & $\checkmark$ & & & \\
\hline Full Local Government or Full Autonomy & & & & & & $\checkmark$ \\
\hline
\end{tabular}

It was observed that half of the participants understood the concept of decentralization as the way in which politics was planned and carried out locally and that it was more autonomous. In this context, P2 stated, "When talking about decentralization in education, I understand it as the way the local government is channeled by the currently centralized National Education organization." P4 more clearly stated that the level of decentralization in the mind is a way of devolution, "The first thing that comes to mind when speaking of decentralization in education that the policies followed in education are planned and carried out locally and that education processes are carried out more autonomously independent from the center." Likewise, P5 said, "In terms of decentralization in education, it is like how these work. Management locally. It depends on the municipalities. The first thing that comes to mind is that education is being done under the guidance of the municipalities." 
P1 emphasized that local governments should support schools financially by emphasizing that "Decentralization in education is more about the ownership of education by local resources or local governments and especially for schools to be supported by local resources" and emphasizing that the localized way of perceiving decentralization is tied to the schools being supported by the administrative and economic local resources. As a matter of fact, P1 supported this view by saying, "I understand decentralization in education in terms of nation-state only as strengthening the economic and physical structures of schools. I mean I tend to think about it like that. Only improving economic structures and physical conditions." P3, another participant, also expressed that decentralization is understood as the transfer of the authorities of the central government to the local governments. "I think that, in the case of local government, I am transferring the powers of the central government to the local governments, to the private administrations, to the municipalities. " P6 perceives decentralization as management and autonomy in its entirety. "It is up to the higher authorities to manage the school in its own right without depending on the Ministry of National Education, without depending on anyone. It is also possible to choose their own employees and work like that."

\section{Opinions regarding the implementation of decentralization in education}

The opinions of the principals regarding decentralization in education have been analyzed with a twolevel thematic approach. The data was first collected under three primary themes: positive opinions, expectations, and concerns. Then, the data related to the first level themes were re-grouped and the second level themes were obtained and the results are presented in Table 2, Table 3 and Table 4.

Table 2

Positive Opinions Regarding Decentralization in Education

\begin{tabular}{|c|c|c|c|c|c|c|}
\hline Themes and Codes & P1 & $\mathrm{P} 2$ & P3 & P4 & P5 & P6 \\
\hline \multicolumn{7}{|c|}{ Theme 1. Positive Opinions Regarding Financial, Physical and Infrastructure Support } \\
\hline I think that the physical conditions of schools will improve rapidly. & $\checkmark$ & & $\checkmark$ & $\checkmark$ & $\checkmark$ & 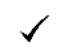 \\
\hline $\begin{array}{l}\text { It is something positive in terms of strengthening the infrastructure of } \\
\text { schools. }\end{array}$ & & $\checkmark$ & $\checkmark$ & & $\checkmark$ & $\checkmark$ \\
\hline $\begin{array}{l}\text { It's a positive thing that schools are economically supported by local } \\
\text { governments. }\end{array}$ & $\checkmark$ & & & & $\checkmark$ & $\checkmark$ \\
\hline $\begin{array}{l}\text { In terms of economic and physical conditions, it will make it easier on } \\
\text { schools. }\end{array}$ & & $\checkmark$ & & & $\checkmark$ & \\
\hline It will increase the number of schools. & $\checkmark$ & & & & & \\
\hline $\begin{array}{l}\text { It can more easily accommodate schools' needs such as cleanliness and } \\
\text { security. }\end{array}$ & & $\checkmark$ & & & & \\
\hline It will ensure more ownership of the school. & $\checkmark$ & & & & & \\
\hline $\begin{array}{l}\text { Local governments can better meet expectations because they can bet } \\
\text { identify local people's needs. }\end{array}$ & & & & & $\checkmark$ & \\
\hline
\end{tabular}

Theme 2. Positive Opinions Regarding the Organizational Structure and Administrative Functioning

Bureaucracy in schools will decrease and tasks, decision-making and problem solving will speed up.

It will increase the authorities and powers of the administrators. It will provide for more autonomy.

I think that the amount of bureaucracy will decrease in more senior administrative offices.

I think the working environment will be better.

It will develop an understanding for participative management in educational institutions.

Concerns regarding job security would increase the performance of employees.

It ensures institutionalization.

Positive opinions of the principals regarding decentralization in education have been collected under two different themes. The positive views were mostly related to financing, the physical environment and infrastructure support, as well as organizational structure and administrative functioning. It is noteworthy that positive opinions on educational practices were not reported. 
With regards to financing, physical environment and infrastructure support, it was emphasized that it will quickly improve the physical conditions of schools and meet its needs. P1 stated, "When there is decentralization in education, I think the physical structures of the schools will be improved first." P6 said, "This way we can get to the resource quicker. We can meet our financial needs easier. That's because currently it's really difficult for the money to reach us from the Ministry, i.e., Ankara. We, as individuals, can better meet our problems and needs. It would be better off through local governments." And P3 stated, "The problem regarding the development of the physical conditions of the school is solved quicker. Students will receive better education under better conditions. In this context, I think that it will be better for our children and for our students."

In similar fashion, many participants emphasized that decentralization is something positive also in terms of strengthening the infrastructure of schools. P2 stated, "When we look at the financial dimension of decentralization in education, today our schools are at financial impasse. You will not receive a donation. You will manage the school without a budget. But you will meet every need. It is contradictory to fulfill all the wishes of the parents. This is why it is no problem for the local school administration to provide cleaning needs, school security, infrastructure work or school needs. Decentralization is positive when referring to infrastructure." $\mathrm{P} 3$ said, "Now, if decentralization in education is to transfer the financial burden to these local governments and its purpose is for the Ministry to be freed of this burden and we are only thinking financially, I think it's a good thing to use local resources to provide for school needs ... For example, the relevant authority could be completely transferred to the municipalities, and the repairing, painting/whitewashing, maintenance and similar needs of the schools can be fulfilled using the resources allocated by the municipalities. I think this would be completely appropriate." P6 said, "This is already the biggest problem for schools and their municipalities when looking at it from a school structure or environmental standpoint. I think it would be easier to provide maintenance, repairs, additional buildings, and so on, if the biggest problems depended upon those municipalities."

The participants also saw the fact that schools are supported economically by local governments in a positive light. In relation to this issue, some participants said:

Regarding decentralization in education, when I think about it from an economic point of view, I do not believe that the expenses of the school are met by the parents or even civilian organizations and the local governments especially the municipalities. For example, our schools believe that repair, maintenance, electrical and plumbing expenses, paint/whitewashing and environmental management can be done easily and smoothly by local governments (P1).

Local governments should meet the funding of schools. It's good to be economically connected to the municipality. For example, the economic support of schools by local governments will help the principals to overcome the economic troubles of schools. Thus, school principals may have more time to engage in education and training rather than in physical space (P6).

Other favorable views on financing, physical environment and infrastructure support that were emphasized were that schools would be more relaxed in terms of economic and physical conditions, the number of educational institutions would increase, the needs of schools such as cleanliness and security would be more easily met, schools would be better equipped and local governments would be able to better meet the needs of the public since they would be able to better identify their needs.

Regarding positive opinions in relation to organizational structure and administrative functioning, it was stated most that bureaucracy would decrease, and as a result tasks, decision-making and problem solving would accelerate. Participants who expressed similar opinions said, "I believe that the problems would be solved quicker, at least I believe that problems will be solved quicker with NGOs and local resources. " $\mathrm{P} 4$ had similar thoughts: "I find it completely beneficial for the school administration to be affiliated with local governments as their upper management. Then, the problems would be able to be solved quicker. Decision-making would be faster. I find it beneficial in that respect."

Another important positive view of organizational structure and administrative functioning is that the powers and authorities of the administrators would increase, and thus more autonomy would be achieved. Participants such as P1 emphasized that the authorities of the administrators would increase and in the end they would become more autonomous by saying, "Delegation strengthens the hands of those employees involved," while P6 said, "We will move more comfortably if we implement 
decentralization. I believe I will meet my goals easier. I believe that the importance of schools will increase even more."

Moreover, some of the participants emphasized that the burden of bureaucracy and centralized authority in upper management would be reduced. In this context, P1 expressed that the burden of centralized administration would be alleviated and bureaucracy would be reduced by saying, "Of course the bureaucracy would decrease, because the burden of the centralized authority would be alleviated."

Other positive considerations were that the working environment would be better, the participatory management approach in schools would be developed, parents would want to participate in the decisionmaking process, job security concerns would increase the performance of employees and institutionalization would be achieved.

Table 3

Expectations Regarding Decentralization in Education

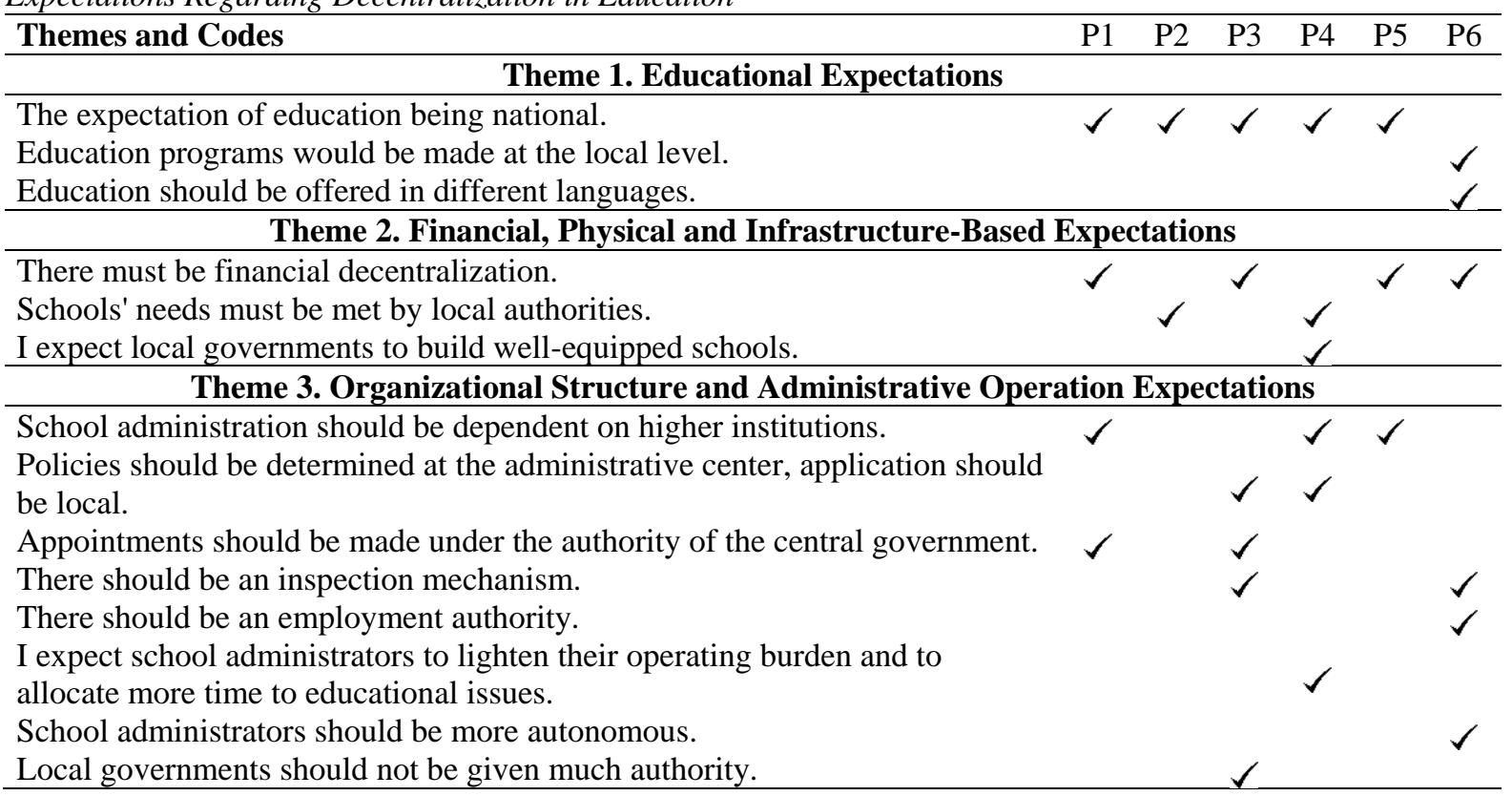

In Table 3, the principals' expectations regarding decentralization in education are gathered under three themes: educational expectations; financial, physical environment and infrastructure based expectations; and expectations regarding organizational structure and administrative functioning.

The most frequently expressed expectation for the education system is the protection of the national structure of education. With the exception of one principal, all other principals emphasized that the education is national. In this context, it was emphasized that the central government should transfer the educational activities outside the national education policies and curricula to local governments, especially if education programs should be at a national level. P1 shared their expectation by saying, "I mean, as long as there are educational programs, there is no trouble in carrying out this work with local administrators or local staff as long as there are joint programs. In other words, I come from the point of view that education is national." Some other participants expressed their thoughts on this subject as follows:

On one hand, we are a nation with a history of around 2,000 years. We need to implement education in this country that will convey this history and culture. When we look at America, if everyone in America says I am American, we want everyone in Turkey to say I am Turkish. This is all we want. We do not pay attention to anyone's race... I think that we need the establishment of an education system ensuring this and a national education system and that these rules should be applied in the same way in the whole country $(P 2)$.

When it comes to what I think regarding decentralization in education, I think it is absolutely necessary to have a national education policy, even if some degree of decentralization will happen. I advocate that education is national and I defend that this nationality should always exist (P4). 
Contrary to other participants, one participant expressed the expectation that the educational programs could be determined at the local level and that the training could be carried out on a separate basis. P6 stated, "I positively embrace it. If we have schools in other countries for our people living in foreign countries, there could be different kinds of education and programs created here. I do not think this will cause a problem. If it is not politically provoked, I do not think it's going to be a problem. They probably think that at the top. It is their only fear. There is concern that this language will be provoked and used for other purposes. Different languages are already spoken now anyways. There is no issue here. The second is that even as a southeasterner I do not think people will be educated in their own language. I do not think it is going too far. I do not know. I am saying this particularly for Turkey. You know the current climate in Turkey. Songs used to be sung in Kurdish. There was no ban on Kurdish songs. It was legal, but there wasn't much more. There was no demand. They listened, and that is okay. Of course, it is better to listen in your own language. Just like going to another country and speaking Turkish is a problem and it is difficult. Let people here speak in Kurdish and speak in Armenian. Let them talk about whatever they want. I support this."

In the context of financial, physical environment and infrastructural expectations, the highest expectation of decentralization was at the financial level. One of the participants, $\mathrm{P} 1$, stated, "Autonomy is economic and as I said, it should be in other areas, especially in the economic area. Autonomy in the administrative sense must be under a central authority." He emphasized that autonomy should only be in economic terms. P3 said, "Yes, if decentralization in education is only considered as financial. This would be nice. I think it would be a positive thing is the Ministry would send money and resources to municipalities and special provincial administrations and resolve school needs through these resources."

P2 touched on decentralization in education supporting infrastructure and superficially meeting school needs as being a positive thing by saying, "Decentralization in education is generally positive when we really look at it, but because of the geographical location and the geopolitical importance of Turkey, different polarizations or different social characteristics between east and west and north and south have emerged, and decentralization is only positive in terms of infrastructure work, since there will be a differences in the west and the negative consequences of the understanding of local governments and the pressure on the staff will create pressure in this direction. Therefore, it is not a problem for the school to provide the local government with its school needs, such as the cleaning of the school, its security or its infrastructure or the school's needs." P5 shared similar thoughts by saying, "If municipalities are to meet the needs of the schools and they are able to meet students' needs immediately, then there will certainly be progress in education."

Another expectation regarding financial, physical and infrastructure support is to build schools equipped by local governments. Regarding this subject, P4 expressed his expectations with the following words, "Since the aim here is to prepare the best for future national education policies in line with the interests, wants, needs and abilities of the children directly entrusted to us, I believe that local governments should be built and equipped for this very purpose. I would like the schools to be built in such a way that they will cover all the social and athletic cultural fields within this goal, and that all their needs will be fully met in the subsequent educational and training processes."

Regarding organizational structure and administrative functioning, the most frequently expressed expectation was that school administrations depend on higher up institutions. Among participants, P4 expressed this thought by saying, "The school administration should depend on a higher up." P1 expressed the view that "Autonomy should be under a centralized authority in the administrative sense" and expressed their expectation stemming from anxiety by emphasizing that schools should be connected to central government in administrative terms. P5 emphasized his thoughts by saying, "It is unthinkable that school principals are in such a place that they would give no accountability to anyone." Another expectation expressed regarding organizational structure and administrative functioning was regarding policies being determined by the central government and only application was to be at the local level. P3 showed that the concept of localized application was a sensitive topic and that there are concerns regarding the educational policies. Regarding this, P3 stated,

For once, Ministry of National Education, the state, should have a basic education policy. This must be determined from the ministry, the center. But I think that authority can be delegated for application (P3). 
Education can be decentralized. A number of problems can be solved through local governments. But I am not in favor of giving authority to local governments for educational policies. Their views can be taken into consideration. These opinions should be assessed at National Education Councils, and of course, as it is currently done, a national policy should be established and disseminated to the country for application and not just staying on paper (P3).

I definitely would say that the basic policy of national education should be determined from the center, taking into account the views of the employees. It certainly should not be compromised. Otherwise, I think it will be very difficult in this country (P3).

P4 had similar thoughts. "Whether or not this is a nation state, I believe that there should be a national education policy. Absolutely. That is because not much is all that important, but the concept of nationality is necessary in order to sustain the nation forever. But in practice, there may be decentralization in decision-making processes. Local administrators at the lower levels may think a bit more independently, more autonomously. But I certainly think that the national education policy applied throughout the country should be determined from a center, that it should not deviate from it, and that it should be strictly adhered to."

Another expectation was related to appointments and transfers of the staff. Two participants emphasized that the appointment and transfer authority should be in the central government because of the politic concerns such as political favoritism. In this regard, P1 stated that the central government should designate administrators by saying, "I am of the view that the administrators still be determined by the centralized authority. Autonomy in an administrative sense should be under a centralized authority." In addition, it was stated that the centralized administration is beneficial in terms of providing intercity coordination in appointments. P3 clarified this issue by stating, "Tomorrow, the teachers will think about this. Let's say I want to be appointed from City A to City B. But if it depends on the local government there, perhaps they do not want me, etc. We need to talk about these things too. A specific basis of everything must be defined. In this regards, the opinions of local governments can be taken into account, but the last word, in terms of appointments, should come again from the center."

Some of the participants addressed the need for an inspection system regarding decentralization. Participants who commented on this issue pointed out that an effective supervision mechanism should be implemented if there were to be decentralization in education. In this regard, P3 touched on the idea that central government should supervise employees by saying, "Central government have to measure and inspect. I am not convinced that in our country it would be very objective in the local government." Indeed, it can be argued that not meeting this expectation is due to a lack of confidence in the inspections carried out by local governments. As a matter of fact, P3 shared that local governments may not act objectively in their supervision of the application. P6 expressed the idea of a supervision system as follows. "When saying it is connected, we need an inspection mechanism. A higher up must be linked to this, i.e., to the Ministry of National Education. That is to say it does not need to be connected in everything. I am not talking about implementing their orders. I am just talking about needing to be connected to the inspection mechanism operation."

As for the other expectations, they are related to school principals being empowered to be more autonomous and that their workloads can be supported through the help of assistants, so that they can spend more time on educational matters and lead educationally. It was also emphasized by one of the participants that local governments should not be given much authority. 
Table 4

Concerns Regarding Decentralization in Education

\begin{tabular}{lcccc}
\hline \multicolumn{1}{c}{ Theme 1. Concerns Regarding Educational Practices } & & & \\
\hline $\begin{array}{l}\text { Themes and Codes } \\
\text { Concern that curricula will stray from the national level }\end{array}$ & & $\checkmark$ & $\checkmark$ & $\checkmark$ \\
Concern about politics in education & $\checkmark$ & & \\
Concern for each local government to determine its own educational policies & & & \\
Concern for political pressure on education reducing the quality of education & $\checkmark$ & & \\
Concern that political pressures on education would make it difficult for & & \\
students to be disciplined & & $\checkmark$ & \\
\hline
\end{tabular}

Theme 2. Concerns Regarding Finance, the Physical Environment and Infrastructure Support

Concern that schools would place an extra economic burden on local governments

Theme 3. Concerns Regarding Organizational Structure and Administrative Functioning

Concern for employee job security and employment

Concern that performance will be ignored

Concerned regarding unethical practice, favoritism and mobbing

Concern regarding favoritism in appointments

Concern that local governments would intervene in the autonomy of school

principals

Concern regarding disturbing peace in the workplace and a decline in the productivity and performance of employees

Concern that it would be difficult to employ staff with political leanings

Concerns regarding low-cost employment by local governments

\section{Theme 4. Concerns regarding Politics}

Concern regarding the deterioration of the nation-state structure

Concerns that local governments would put administrative pressure on educational institutions

Concern that schools would be instrumental in conflicts between power groups at local level

Concern that there would be different educational policies at the local level

Concern regarding the weakness and ineffectiveness of opposing political

structures

Concern that political pressures on educators would increase

Concern that local administrators would behave in a populist fashion

The negative opinions principals hold of decentralization in education have been gathered under four themes: concerns regarding educational practices; concerns regarding finance, the physical environment, and infrastructure support; concerns regarding organizational structure and administrative functioning; and concerns regarding politics.

The most frequently expressed concern regarding educational practices was that the curricula would stray from the national level. Participants believe that, with the decentralization of the education system, the curricula would be determined by the local government, thus detracting the education system from the national level and damaging the structure of the state. This suggests that there are political concerns underneath the concerns regarding the decentralization of the education system. P4 states that he is concerned about this: "Education must be national. If education is not national, different generations would arise from the different cultures. I think that some negative aspects could occur when trying to be a nation. If there is not a national education policy, as I said, think of a chain link that is contrary to the others, contradicting with each other, just as it was in Ottoman times. The chain links would all be going in different directions. So there would not be integrity. In other words, if we want to get to where we want to get, the goal we want to reach, we have to have integrity within all of the links of this chain." Another concern was the politicization of the education system. P2 clearly expressed this concern by saying, "The neighborhood president from the ruling political party would immediately see himself as the boss of the school. Or, in any regards, those voting for this political party would see themselves as the boss of those who work at the school."

Another important concern expressed was that each local government would have its own educational policy. In this regard, P3 stated, "If every local government would determine National Education policies through its own eyes, this would be wrong." P6 expressed their concern that different 
educational policies might be implanted throughout the country by saying, "If we were connected to municipalities, this could be a problem. I think that things might change according to political views." Furthermore, P2 stated, "Political parties in some provinces, especially those that are geopolitical or population dense, and that are more industrialized, would fight more for local governments. That is because everything stems from there. A party that obtains local political powers in those provinces would have the power to determine education policy altogether. This, of course, would give them the opportunity to raise up generations more sympathetic to their own views."

Other concerns related to the education system were the concerns that political pressures on education would undermine the quality of education and make it difficult to discipline the students. P2 expressed their concerns about these issues as follows. "In an undisciplined environment it would not be possible to educate and the student would be most negatively affected here. That is because a parent who puts pressure on the teacher would not end up seeing the teacher as an authority figure. I think that they would see them not as a person to be respected, but rather as a person to be bossed around, and as a result a disorganized educational environment and the education that would also emerge from that disorganized educational environment would result in an unsuccessful educational experience." With regard to disciplining students, $\mathrm{P} 2$ also said, "When we think about the student, there might be a situation that prevents us from disciplining the student at all. This is because the student and their parent might reach out to the local governments in various ways and put pressure on the teacher and the school through the local government."

Regarding concerns about finance, the physical environment and infrastructure support, only education institutions were concerned about placing an extra economic burden on local governments. In this regard, P2 said, "Local governments would see it as a plus, because they would have a say in the educational institutions that are raising up the future generation, and on the other hand, they would see it as a negative burden due to the financial burden that comes with it. Concerns might arise if the schools were not able to come up with sufficient finances from the centralized budget and as a result the schools not being able to meet their real needs. In that case, they would have a greater burden."

In the context of concerns regarding organizational structure and administrative functioning, the fact that all participants raised the concern of employment and job security is important. Regarding this, participants expressed their concerns on several occasions (25 times) even while talking about different issues. In this respect, it was the most frequently expressed concern in the study. In terms of the job security, they emphasized concerns regarding job security due to political favoritism and they were not open to decentralization in education. Some of the participants say those:

I would guess that everyone's mutual concerns would be job insecurity and finances (P1).

The decentralization of appointments and the relocation of training staff, I think, would have a negative and not a positive effect on education. That is because local governments would follow their political leanings, and, as a result, they would end up applying pressure only on people who are opposed to their own political leanings while tolerating whose who agree with them. Appointments and relocations would be completely personal, completely politicized. This would destroy educational peace of mind and unity. As injustices against educators would come to light, it would demoralize other educators. They would end up preferring not to work (P2).

Teachers would have a heap of concerns. The first concerns would be in relation to job security. Teachers who do not do their job very well would think about what would happen to them. Or even if they do their job well, they would directly try to make overtures to the local administrative authority. I don't know, they would spend a lot of efforts keeping their places. I would rather wish that these efforts be used for education and teaching (P3).

Staff may be concerned politically if decentralization were to come about in education. That is, if local political authorities appointed school principals due to decentralization, or if the local political authorities have a very clear influence over the educational institution, the teachers might be concerned politically or they might be constantly concerned about job security. Teachers need to have $100 \%$ job security. Again, if local political authorities were completely empowered, they could emerge as a tool to put pressure on school principals. I am concerned about the influence these political powers in local governments would have on the appointment, relocation, and advancement of school principals $(P 4)$. As local governments change, if the parties change, they might cause problems by changing the school administration. If continuity is important in education and if anyone coming to power considers 
changing the school administration and their teachers, why not place my buddy, sergeant, or relative there. If they would not protect the social security of educators, it would not be good if speaking from an educational point of view. We really do not like this guy. If there were thoughts such as today this person treated my relatives bad so I'm going to fire him, we're paying this person any way, it's going to result in bad things happening. It would cause trouble. Employees would not be able to be free then. Teachers need to be free in these kinds of things. When the teacher concentrates on a lot of things, s/he would not be very productive, because s/he would not be able to attend to the people in the class. For this reason, teachers would not be able to teach children freely when they are in places where they feel themselves threatened with such things. That's what I think. (P5).

I am concerned with them if they were to be tied to municipalities. I would say that municipalities might cause political problems when elections are held. There might be a constant change in administrations. That is my only concern. Just as I said, I think workers might be concerned about losing their jobs for political reasons (P6).

Another important concern expressed regarding organizational structure and administrative functioning was that performance could be ignored. Among the school principals who commented on this, P2 referred to the fact that the politicization that decentralization could bring may lead to unchallenged appointments, thus increasing the employment of non-performing and incapable administrators and teachers. "In the school where our child goes, is the teacher really working because s/he deserves it or because s/he agrees with the administration politically? Is this person really productive and giving his/her all? Or if s/he's not is it simply because of s/he is close to the authorities? We would be concerned about this." P2 also believes that politics and political performance would be emphasized. "I think that local governments would be active in educational institutions, their initiatives would be more active, and so that it would become compulsory for people to work wherever their leanings line up with the local government. I think that political views and political leanings would take preference over qualifications and performance." P5 mentioned that qualifications would be ignored and people finding jobs based on who they know would become widespread by saying: "Everyone knows someone who has political power or someone who carries out those things that I said. There's definitely someone who s/he is buddies with or who was his sergeant. ... S/he says I know a teacher here. S/he says we should employ him. It becomes something that they are going to take care of. Such a problem could arise."

There was also concern that unethical practices, mobbing and favoritism would increase. P2 expressed that concern by saying, "I am worried that if decentralization in education came into being, it would not be able to ensure objective criteria." P5 said, "With decentralization, when a different administration were to come into power, the first thing that comes to mind is, let's say, if the person in power goes and another person comes in, there would be a very painful injustice without any consideration for what people do. I mean as school principals. Think about this. You are assigned to an exam, but what happens when those places are looked after by proxy? For example, people who are close to the current power would be assigned. People also think that rewards would also be based on this, and this is often talked about. This is something frustrating. Or there is a complaint filed against the teacher. This would end up being a lot simpler. I did not like the teacher's thought on that; I was sick of this guy. Let's fire this guy from the school."

Another concern addressed in the context of favoritism was the non-objective practice of appointments. $\mathrm{P} 3$ expressed their thoughts as follows. "For example, with appointments, it is absolutely necessary for the local commission to make a statement regarding my appointment, to make some arrangements to prevent subjective rather than objective decisions. Otherwise, I think that if we gave too much authority to local governments, it would be unbearable."

Another concern was the concern that local governments would interfere with the autonomy of the school principals. In this regard, it was thought that the powers of the administrators would become restricted. P1 expressed their thoughts on this issue by saying, "Even if we were having so much trouble with the central government, I think that our place of action would be further restricted when local governments are concerned. The administrator, who is constantly prevented from working in this restricted place of action, would no longer attempt to work anymore after 3 months, 6 months, 1 year, after a certain period of time."

Other concerns emphasized the deterioration of employee comfort and a decrease in the productivity and performance of the employees. In addition, there is concern that it would be difficult to employ 
people who have political leanings and that local governments might be able to operate a cheap labor force. In relation to this subject, some participants said:

There would be parental pressure. I do not believe that a very productive environment would emerge. This, of course, would ruin people's comfort. People would become less productive as the business would fall apart. In short, I think that political opinions and political leanings would prevent qualification and performance. Like I said, what I care most about this matter is personnel relocation and appointment. It stems from the concern that local admissions would act subjectively. Because of this concern, people would not be able to work in peace (P2).

If the school were to be a source of revenue, the municipalities would want to manage the school. If schools were wretched and a money source was not coming to the schools, they would not want to invest in the schools ... Let's say that this school's budget is 1000 TL. This would be cost 600 TL for personnel. They would say to the school principals: Friends, we are going to find teachers who will work here cheaper. Newly graduated teachers. They might say we should get some of these kinds of teachers (P5). I think that if you were to tell the teacher something, tomorrow it would cause pressure to be put on us. Or when we request something, we might worry that they would reply I have a lot of support behind me and we don't care about your request, so we're not going to fulfill it (P2).

The last theme regarding concerns expressed was regarding negative thoughts stemming from politics. Under this theme, the most frequently expressed concern was the concern of harming the state structure. P2 talked about decentralization in education unitarily harming our state structure by saying, "Of course you can have a sense of power when you are the arbiter, as if I have the money so you need to listen to me. Then, I can manage the educational institution in the way that I want, and they end up acting out of that logic leading them to create an education system according to their own opinions leading them to even unitarily deteriorate our current structure. In other words, this is not the case for every municipality but if we look at our country as a whole, we can see that this is the case at least with some of our provinces." Similar considerations were conveyed by P4 by saying, "In fact, it is absolutely useful for the school's administration to be affiliated with local governments as a higher administration. However, as I have just pointed out, in some parts of our country due to the reality of terrorism in our country, we are anxious and worry. Normally, if this terrorism were not to be around us, it would be very helpful to have schools affiliated with a local higher authority. I also believe that this is the case in Europe. Then, problems would be able to be solved more quickly. Needs can be met quicker and faster. Decision-making can be quicker. I find it useful in that respect. But as I said, I do not think that there are separatist movements in some parts of our country that will bring beneficial results to our country in those regions. I am concerned about that ... I would be concerned about preserving the integrity of this country as I mentioned at the beginning."

Another political concern was related to the fact that the local governments may have a say in schools. In this regard, P2 was stressed that politicians would try to put pressure on schools and people and schools close to the local government in power would try to take advantage of educational institutions by saying, "Local governments would have a say in schools which are preparing the future generation... Of course, unfortunately, there would also be people and institutions who would want to take advantage of them. There are those types of people, but there are also institutions who really are in it just to please God. Of course, there would be conflict between the two. Those with similar interests as the local government would of course work to take advantage of them and profit from them. Which is what I think would happen in the end."

Another thing that was also mentioned was that educational institutions might be disturbed by the fact that at the level of local governments, power groups could be used as a tool in conflicts, different educational policies at the local level could be developed, and they might not be able to be held in a structure with opposing politics. In addition to this, there was a concern expressed that the political pressure on educators might end up increasing, the pro-political teachers and the parents might end up putting pressure on the educators, educators' peace of mind would be destroyed and local administrators might take a populist approach. 
Opinions regarding how decentralization in education would be beneficial

Opinions regarding how decentralization in education would be beneficial in Turkey were gathered under five themes: suggestions related to the political structure, suggestions related to organizational structure and work, suggestions related to funding, physical environment and infrastructure support, and suggestions related to educational practices and proposals regarding the inspection system.

Table 5

Opinions Regarding How Decentralization in Education Would Be Beneficial

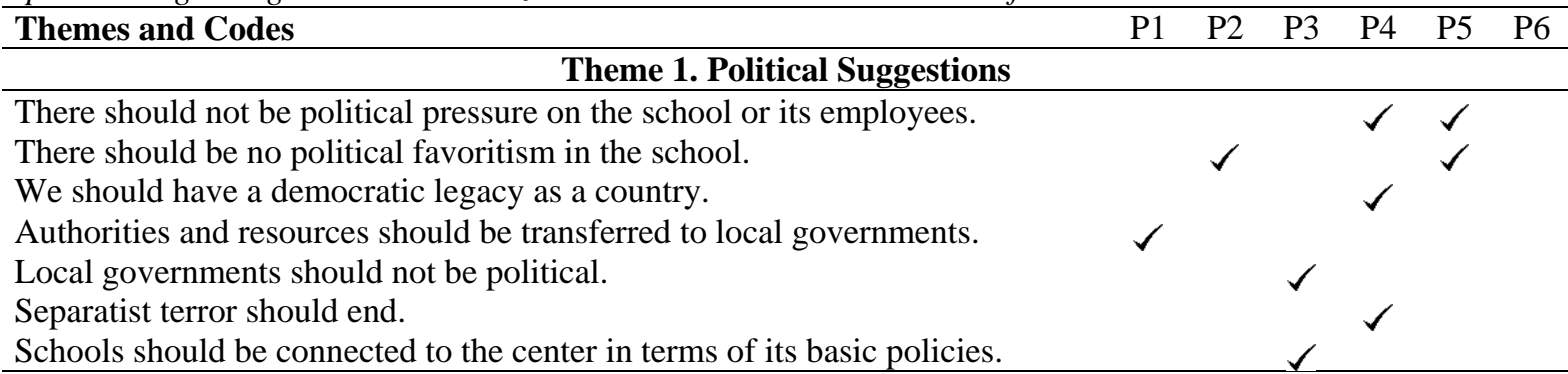

Theme 2. Suggestions on Organizational Structure and Administrative Functioning

Appointment, relocation and firing should be based on an objective attitude.

The principal and stakeholders should manage the school.

The autonomy of schools should be increased.

Employee rights should be increased.

There should be job security.

The principal should be the president of the school board.

There should be educated people at the head of the school's board of

directors.

Educational administration is a professional occupation.

The principal should be engaged in educational issues.

The opinion of the principal should be taken into account, but s/he should not

have full authority.

At the workplace, the school administrations should be autonomous.

Personnel employment and appointments should be made by central

government.

The school principal should be appointed by the school stakeholders.

Schools should still be attached to a higher institution. They should not be

fully autonomous.

The number of school staff and administrators should be increased.

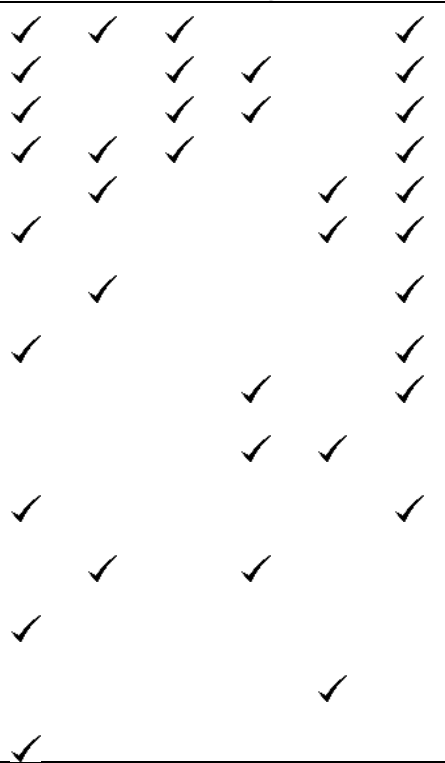

Theme 3. Suggestions on Financial, Physical and Infrastructure Support

Local governments should provide financial, physical and infrastructure support to schools.

There should be financial (economic) autonomy.

New schools should be built.

Theme 4. Educational Practice Recommendations

The curriculums should be determined by the central government.

Curricula should be national, with some flexibility.

Education policies are determined by central government.

Theme 5. Suggestions for the Inspection System

Employees should be objectively assessed.

There should be a centralized investigation center, but it should take into

account stakeholder views as well.

The investigation policy should be determined by the central government, but

delegation can happen in practice.

There should be internal and external inspection. The school principal should

do the interior inspection. Higher institutions or independent organizations

should do the exterior inspection.

Schools should be supervised by local governments.

Regarding politically motivated suggestions, two participants pointed out that there should be no political pressure on schools and employees, as local governments might want to have a say on schools. 
P5 said, "They shouldn't be too familiar with too many parents. That is, they shouldn't be too familiar with parents or politicians outside the school. The first person of responsibility should be the school principal. The school principal shouldn't be trampled on, and the principal should be able to prevent political pressure. If they are, perhaps the problem can be reduced politically." Similarly, it was mentioned that there should be no political enthusiasm in schools. It was touched on that favoritism might come about as local governments might want to be influential in the school administration. P5 said this about the subject. "From a political standpoint, there should be equal spending on schools. If one school has a lot of investments made on it and yet there is a problem with the heating of another school and it is not taken into consideration, if they are not treated equally, it will always cause problems politically."

Other politically motivated suggestions were to be able to have democratic maturity, to delegate authority and resources to local governments, to remove local governments from politics, to finish off separatist terrorism, and to have the basis of schools connected to a centralized authority politically. Some of the participant opinions on this subject were as follows:

I believe that this separatist terrorism in our country should be finished off before anything happens regarding decentralization in education. As I said before, for me that is the first condition that must be met... I think that attention must be paid to separatist terrorism (P4).

The municipalities should be removed from politics. There shouldn't be a president of party $A$ and the president of party $B$ in the municipalities. I think there should be candidates. Candidates would be selected. The mayor's office would not be political. It would be removed from politics (P3).

With regards to suggestions related to organizational structure and administrative functioning, one of the most emphasized issues was to display a qualification based objective attitude in terms of employment, appointment, relocation and firing. In this regard, P2 touched on the need to be wary of abuses in appointments by saying, "Yes, I mentioned it at the beginning. Once work conditions and relocation conditions and administrator appointment criteria are objective, precise, and clear and people can work in their institution comfortably, that is, when they stop worrying about whether or not they will be drug around or that they would employ me and do this or that, then it will be positive for authority to be delegated to local governments and for the local governments to meet the needs of the schools." P6 touched on the need for firings to be objective by stating, "Firing should be done using objective criteria, and observing based on objective performance standards. No one should be wronged. I worked in a foreign company before becoming a teacher. No matter how people they fired, they fired them rightly and if necessary paid them a severance wage." P6 again mentioned that firing should not be done by the school administration but rather by a higher up institution by saying, "I think that the authority for firing should not be delegated. But, of course, the school board can prepare and give the necessary paperwork, documents, and recommendations to the higher authority, that is, the inspection mechanism. The inspection mechanism could be a judicial board. I would say that they'd evaluate it and make a decision based on that. The same would be done in a normal disciplinary investigation. So at the place of employment, the school administration should be autonomous. It should be able to employ but only make suggestions based on objective criteria regarding firing." Similarly, P3 and P1 emphasized that the recruitment of personnel should be both loyal and objective. In this regard, P3 stated, "When administrators are appointed, it should be based on objective criteria rather than my man, your man ... A system should be established that is based on objective criteria that can distinguish one who does his or her job and one who does not, and everything should be demanded from a teacher. Only by doing this would it gain momentum." P1 said, "Educational institution administrators should also be appointed by independent committees, giving importance to qualification and their career, and the exam should never be overlooked."

Regarding suggestions made about organizational structure and administrative functioning, one of the most mentioned was related to the management of schools by a board of directors consisting of its principal and its stakeholders. In this regard, P4 stated that it would be beneficial to the school to be ran by a school board made up by its stakeholders by saying, "The school should not be managed only by the school principal. That's how it used to be. Schools should definitely be managed together with its stakeholders according to a participatory management understanding. It could be a school board. The board of directors could be made up of the school principal, a representative of its stakeholders, a 
student representative, a parental representative, an NGO representative. Local governments might also be represented. This could be a possible administrative unit. But the school principal should be right in the heart of it. S/he should be right at the center... S/he should be in it and be the president of the board." $\mathrm{S} /$ he also emphasized that the school principal should be the head of this board.

Another important suggestion was to increase the autonomy of schools. Regarding autonomy, P4 said that autonomy needs to be ensured by saying, "I think that if there is decentralization in education, it should be administrative. I do not find the type of administration where everything comes from a centralized unit very useful. But not completely. In other words, I think that there should be local autonomy in terms of problems that can be easily solved locally." P6 defended the idea that schools should not be run by a higher institution and that they should be autonomous outside of inspections by saying, "The school should not necessarily be directly connected but there should be something. There should be place for it to be connected to an inspection mechanism. It could be the Directorates of National Education or maybe municipalities. It needs to be under some sort of inspection. Schools need to be governed by higher institutions, but schools should be autonomous except for investigation."

Another suggestion emphasize was the improvement of employees' existing personal rights. Emphasis was placed on giving educators the value they deserve both economically and emotionally and keeping and improving their current personal rights. P2 stated, "That is to say, their current rights have to be kept. "In particular, the proposal to protect existing employee rights shows that employees are concerned about the loss of individuality that may arise from decentralization. P6 stated that it would positively affect the performance of educators for individual rights to be improved by saying, "I believe that if the economic conditions of the employees were improved, performance would increase even more. But it must be done professionally. The teacher or the employee needs to be in the place where they don't need an additional job. What I am saying is that economic conditions need to be fixed." Similarly, P3 stated, "If we want to increase educational quality, we need to improve the quality of teachers to the same standard found in European countries. Today, however, our teachers still often yell. It's our individual right. We don't get along, etc. For one thing, teachers wouldn't have such a problem."

Another recommendation that supports the proposal of protecting and improving employee rights was with regards to job security of employees. Similarly, this suggests that workers are concerned about the loss of jobs that may arise from decentralization. P2 talked about the need for job security by saying, "As I said, people should be treated according to their work rather than their personal political views. That is why people should never lose their security. Job security is the security that people are looking for most. When you do not have job security, are you worried and afraid that they end my job today? It is probably not right for us to talk about how meaningful and productive a lesson is if it's given by a teacher who is wondering whether or not they will be fired from the school or institution that day." P5 stated that those that are performing well should have job security by saying, "Job security needs to be ensured. It might be the same as in the previous system, for example, say 657. But it could be a little bit more flexible, too, not necessarily for the benefit of the staff. That's because there are people who do not work very hard in National Education. They must be weeded out. It could be an indicator of performance." Indeed, P5 is concerned with the loss of unjustified work that might be caused by favoritism through subjective measures that could arise from decentralization, referring to the fact that job security should be linked to objective measures.

One of the suggestions regarding the school administration was related to the fact that the schools should be managed by a board of directors and that the principal should be its president. P1 openly spoke of this by saying, "Of course, the school principal should be the president of the board. I think s/he should use the authority invested in him or her by the board of directors." P6 supported this by saying, "I think there should be a board of directors. That's because a single school administrator alone is not democracy. I think that decisions should be made through a board decision so that there are no differing opinions. Everything needs to be done by board decision so that there is no thought such as what is the administrator doing with the money or what is s/he doing with the grant that was given. This, of course, requires a board of directors. And, I think the school principal needs to be the president."

P2 and P6 also emphasized that educated people need to be at the head of the board, P1 and P6 emphasized that educational administration is a professional occupation, and P4 and P6 emphasized that principals can divide most of these educational issues into either time or labor when speaking of educational quality. Some participants said of this issue: 
I would say that it needs to be managed by someone who is educated. This is the first requirement. This needs to be the red line. There needs to be a professional administrator who understands education. I mentioned it in the previous questions. As the name implies, that professional administrator should be involved with education. S/he should not be involved with just the repair and maintenance of the school. 90\% of current school principals think completely about how they can make the school better. The physical structure is focused on and education is put on the backburner (P6).

S/he needs to be an educator as well. That is to say, s/he needs to have tasted chalk. That's because it's easy to just talk for those who have not tasted it and experienced its difficulties (P2).

But again I would say that the school administration needs to be separated from the running of the school. Definitely. If we improve the quality of the education in this country and further develop our schools, we need a different way to run the schools. The school principal needs to be the educational leader. Or at least take on that role more. In other words, s/he needs to have a certain amount of effect and influence when running the school. But I think his or her primary role must be to the educational leader (P4).

Some of the participants held the opinion that the school principal should not only offer his or her opinion when employing personnel but that s/he shouldn't hold all authority. P4 stated, "I think it would be beneficial to receive the opinions of the school administrators when employing personnel. But I do not think it would be right to have the school administration make all employment decisions. " P5 stated that the school principal should have some say in employing personnel but that s/he should not be the only one making the decisions by saying, "Of course, there needs to be some criteria when employing personnel. The potential employee needs to have a diploma, they need to have this and that. But besides this, for example, if five people are going to be involved in the employing of personnel, one of them needs to be the school principal. I mean, the school principal shouldn't say I'm employing this person, he's my brother, etc. And, it needs to be the same way when firing. When the school principal brings up the subject regarding firing an individual, it needs to be determined whether or not their assessment is correct. This needs to be evaluated. That is, it can't all be left up to the school principal's will and disposition." However, some different participants felt that school administrations should be fully autonomous in employing personnel. With regards to this, P1 expressed his or her opinion as follows. "From the perspective of employing personnel, autonomy is the strongest thing you can give a school principal. It should be autonomous. Some things should be met from the private sector, not the public, for example, purchasing services or employing personnel. In particular, assistants."

P2 and P4, unlike P1 and P6, advocated that staffing and appointments should be made by the centralized administration. "But as I said, I think that the general policies and education curricula should be produced by the centralized administration and that the personnel relocations should be done in line with the principles set forth by the centralized administration."

Other suggestions regarding organizational structure and administrative functioning were that school principals be assigned by school stakeholders, the number of staff and administrators in schools be increased, and schools not be fully autonomous.

Regarding suggestions related to financing, the physical environment and infrastructure support, participants suggested local governments provide schools with financial, physical environment and infrastructure support, that financial autonomy be provided to schools, and new schools be built to increase the number of schools. In this context, some participants said:

Autonomy, I think, should be limited to just a few areas. For example, in economic conditions, in environmental education, in the development of educational opportunities, and in new social and cultural activities (Pl).

Local governments should be directly involved in the financing of their schools. I believe that finances should be left entirely up to local governments. (P4)

The fourth theme with regards to decentralization in education was the theme of educational practices. In this regard, participants suggested that educational programs be determined by a centralized administration, that national curricula be nationwide, and educational policies be determined by the centralized administration. Some participants' opinions on the subject were as follows: 
I think that educational policies should come from a centralized administration rather than local governments, and that the central government should create educational policies and that the future be shaped based on this. This way, I think it would be very productive. There needs to be a single framework curriculum for the whole country. As I said, we are a very mosaic nation. If every people group or people living in this nation were to come up with their own education philosophy, it wouldn't be possible to even talk about unity in this country within a decade (P2).

Of course, I think some courses having the same curricula is a must. In other words, it wouldn't work for local government $A$ and local government $B$ to have a different curriculum program. However, perhaps flexibility in curriculum programs could be mentioned. A flexible structure could be provided that would be adaptable to that region. But, as a basic policy, it needs to be determined by a centralized administration (P3).

I believe that the curriculum should absolutely be determined from a center and that it should be national. There's no buts about it. I think it should be determined by a centralized administration (P4).

The last theme of suggestions regarding decentralization in education related to the inspection system. In this regard, suggestions were made that evaluations of employees should be made according to objective standards, the inspection system should be connected to the centralized authority but that stakeholder opinions should be taken into account, that the investigation policy should be determined by the centralized administration but that the authority may be delegated in practice, that schools should have both internal and external inspections, that the school principal should do the internal inspections and higher or independent institutions should do the external inspections, and that schools should be inspected by local governments. Some participants' opinions on the subject were as follows:

These people's success should be rewarded and those who work fair should be respected and fairly judged. As I said, people should not be treated according to their political views ... Employees should be checked on and evaluated according to objective criteria (P2).

There needs to be an inspection system based on performance and they should be scored based on that ... This inspection mechanism should also be determined by the centralized administration. I think that the application of it should be delegated. That is, the same control system should be applied throughout the country. Otherwise, there shouldn't be a different approach to inspections in Burdur than there is in Antalya (P3).

On the topic of inspections, I think it would be right for education inspectors to be connected to a centralized administration. But that's not enough. I think it would also be good to get school stakeholder opinions through various surveys, satisfaction surveys, etc. That's because education inspectors' inspections would be limited to one hour, two hours, or perhaps 2-3 full school days. But in the provincial Directorate of National Education, it would be beneficial to continue the inspections through higher up institutions. These are already centralized administrations anyways. However, as I said, I believe that school stakeholders and parents should definitely have their opinions taken into consideration to an extent through satisfaction surveys (P4).

The school principal needs to inspect his or her school. The first inspection needs to be done by the school principal. I'm talking about inspecting it all the time. It just needs to have an inspection once a year every other year. Responsibility should fall on the school principal. When needed, those who provide direct guidance should come and do it as well. So let's say a new system has been implemented. The people responsible for the supervision of this system should give guidance directly to the schools... It is also possible to have the school inspected by independent institutions (P5).

\section{Opinions regarding decentralization models}

In this part, first, opinions of the principals regarding decentralization of different educational processes were investigated and presented in Table 6 . Then, holistic opinions on decentralization in education were summarized in Table 7. 
Table 6

Opinions Regarding Decentralization of Different Educational Processes

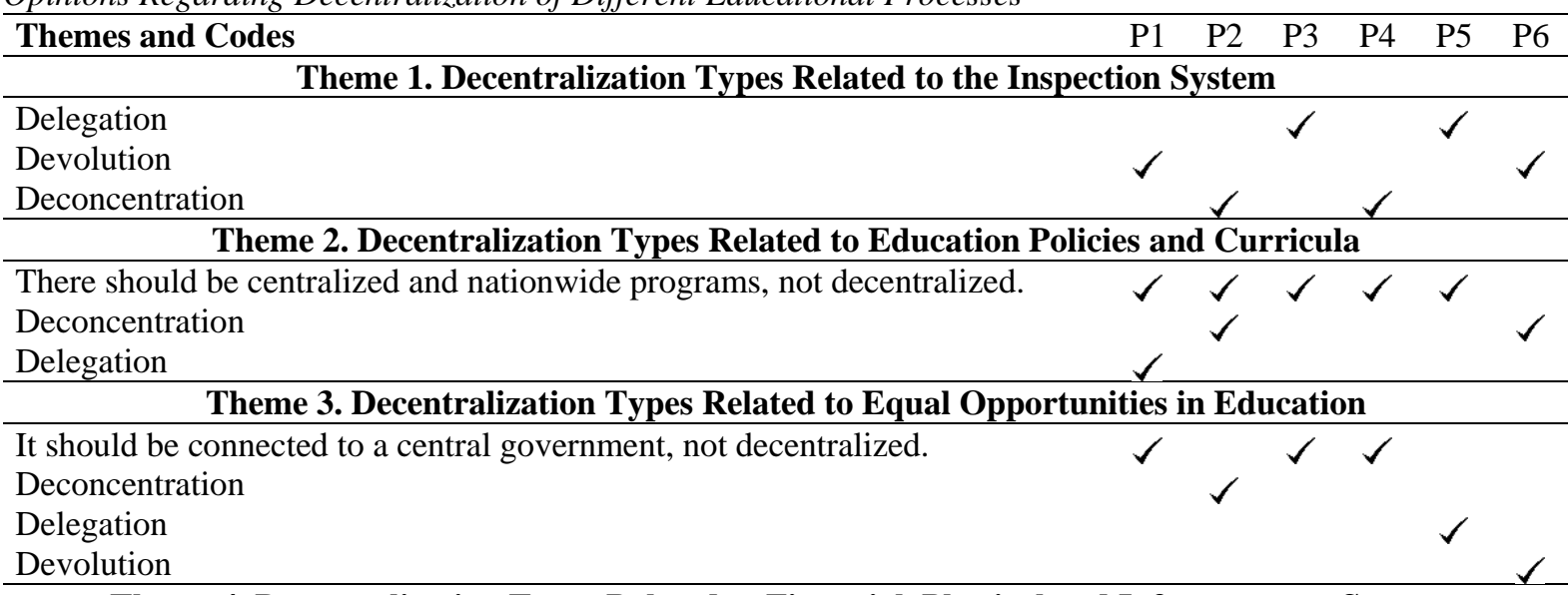

Theme 4. Decentralization Types Related to Financial, Physical and Infrastructure Support

Delegation

Devolution

Theme 5. Decentralization Types Related to Quality and Performance

\begin{tabular}{lcccc}
\hline Devolution & $\checkmark$ & & $\checkmark \checkmark$ \\
Delegation & & $\checkmark$ & $\checkmark$ & $\checkmark$ \\
\hline
\end{tabular}

Theme 6. Decentralization Types Related to Organizational Structure and Administrative Functioning

Delegation

Devolution is not appropriate.

Devolution

It should be connected to a centralized administration, not localized.

Deconcentration

Devolution

\section{Theme 7. Decentralization Types Related to Personnel Employment}

In terms of the opinions of the principals towards the inspection system, P3 and P5 supported delegation, P1 and P6 supported devolution, and P2 and P4 supported deconcentration. Some of the participants' opinions on the subject were as follows:

My opinion is that if this is done it should be through delegation. I think that the situation does not warrant implementing the others (P3).

There needs to be inspection, and it could come about through devolution (P6).

I certainly do not advocate the delegation of inspection to local governments. However, it could be delegated to sub-units of the centralized administration. In fact, today's system is rather close to this. I do not advocate the devolution of the inspections either. But I rather have deconcentration to lower levels (P4).

In terms of educational policies and curricula, P2 and P6 supported deconcentration and P1 supported delegation. In terms of devolution, decentralization was not preferred when speaking of educational policies and curricula. In addition, according to P1, P2, P3, P4, and P5, educational policies and curricula should be nationwide and determined by a centralized administration. However, only P1 and P2 struggled with this. Due to their concerns, both participants did end up emphasizing that educational policies and curricula should be nationwide and shared throughout the nation. P3 also stated that there would need to be some flexibility, providing that it adheres to centralized educational policies. Some participants' opinions on the subject were as follows:

The curriculum needs to be prepared according to certain regions. It could take place through deconcentration (P6).

We are in favor of devolution. In other words, devolution in terms of curricula (P1). 
In terms of curricula, I believe that it should be determined entirely from a centralized authority. In the current state, the Board of Education determines this. It's the same way. That's because if we argue that education should be national, it needs to be determined from a centralized authority (P4).

In terms of equal opportunities in education, $\mathrm{P} 2$ supported deconcentration, $\mathrm{P} 5$ supported delegation, and P6 supported devolution. As for P1, P3 and P4 from the perspective of the provision of equal opportunities in education throughout the nation, they desired for there to be no decentralization in this area and that the centralized administration's authority and responsibility would offer equal opportunities. Some participants' opinions on the subject are as follows:

Of course, the central authority would talk about equal opportunity here (P1).

If transferred to local governments, equal opportunities in education might not be possible. Politics could come in to play here. Kinship could come into play. Friendships and relationships could come into play. Equal opportunities might not be possible. However, if it is determined from a centralized authority, I think it would be ensured (P4).

I think devolution would reduce equal opportunity. Maybe because of our experiences, we believe this to be true. Deconcentration is more objective in terms of equal opportunities, because in a centralized system, assignments would be made according to a performance score without taking into consideration name/surname, ethnicity, or religion, and deconcentration would be implemented or the place of assignment would be determined. I think that this would ensure equality between people (P2).

I would say that for equal opportunities in education we would need devolution. I think that it shouldn't be private but autonomous (P6).

In terms of financial, physical and infrastructure support, P2, P4, and P5 supported delegation and P1, P3, and P6 supported devolution. Some participants' opinions on the subject were as follows:

As I said, I don't think that with some things it would be a problem for local governments to determine the educational philosophy and determination of curricula and providing job security for employees as well as meeting school needs such as equipment, infrastructure, cleaning and security of the schools as long as the Ministry has the final say. In terms of financing education institutions, I think that delegation is much more appropriate (P2).

Devolution would completely work in terms of finances (P3).

In terms of quality and performance, P1, P5 and P6 supported devolution and P2, P3 and P4 supported delegation. Some participants' opinions on the subject were as follows:

I am of the perspective that we should try delegation initially and observe it and then we can respond to such a question, perhaps because of my concerns regarding the subject (P3).

When we are talking about it being good quality or very good, it can come about through devolution or privatization. Unfortunately, that seems to be a bit better (P5).

In terms of organizational structure and administrative functioning, P1, P2, P3, P4 and P5 supported delegation. P6 advocated for devolution. Moreover, P2 and P4 emphasized that devolution would not be appropriate in terms of organizational structure and administrative functioning. Some participants' opinions on the subject were as follows:

I think that delegation might be more appropriate in the context of the administration. As I said, as long as we pay attention to certain areas (P2).

I believe that it would be useful to delegate in such a way that the main responsibility would lie with the centralized authority but everything wouldn't be carried out from the centralized authority and some authorities would be delegated in such a way that if there was any deviation from the foundational policies that it could be fixed easily and immediately $(P 4)$.

From the perspective of the administration, I think that devolution would be appropriate in terms of decentralization in education (P6). 
In terms of the administration, it would be beneficial for devolution to lower units and recognition of their autonomy to take place. It would be useful. That way work could get done quicker. Decisions could be made quicker. There would be faster application. It would be beneficial in terms of finding quicker solutions and many other similar things. However, as I said, these powers could be used with bad intentions because of the terrorism that exists in our country. It could be used to separate. Because of that I do not support devolution (P4).

In terms of employing personnel, P2, P4 and P5 supported delegation and P1 and P6 supported devolution. According to P3, employing personnel should be connected to the centralized authority. Moreover, P2 stated that decentralization regarding employing personnel could also happen through deconcentration. Some participants' opinions on the subject were as follows:

Because of the reasons we've already mentioned, in terms of personnel employment privatization wouldn't work in terms of employing, firing, salary, and individual. I would advocate delegation to the local organization (P5).

I definitely don't advocate the delegation of personnel employment to local. Again, it's because of the conditions I've already mentioned. I'm talking about local units employing personnel. I'm talking about local units of the centralized administration. I certainly do not advocate for it to be delegated to local governments. I advocate delegation to the local units of the centralized administration. I've already mentioned this, or even the provincial Directorate of National Education could do it. It doesn't necessarily have to be the province or governorships (P4).

Everyone should be able to choose their own people. The board needs to be able to choose them itself. They need to be able to choose their employees, including their schoolteachers. It would be through devolution. It shouldn't be private, but it should be autonomous (P6).

In terms of personnel employment, privatization could cause a problem here when talking about employee rights. The same could be true of devolution. In order for these things not to cause an issue, I think that it would be better for the personnel staff to be connected to the centralized authority (P3).

Table 7

The Holistic Opinions of the Principals on Different Types of Decentralization in Education

\begin{tabular}{lcccccc}
\hline Opinions & P1 & P2 & P3 & P4 & P5 & P6 \\
\hline Delegation & $\checkmark$ & & $\checkmark$ & $\checkmark$ & & \\
$\begin{array}{l}\text { Deconcentration } \\
\text { Devolution }\end{array}$ & & $\checkmark$ & & & $\checkmark$ & \\
\hline
\end{tabular}

Furthermore, it was asked of the participants as to what their decentralization style preference in education would be as a whole. P1, P3 and P4 supported delegation, P2 and P5 supported deconcentration, and P6 supported devolution as it would be more appropriate to our nation. Some participants' opinions on the subject are as follows:

I would say delegation. But in different areas of work, for example, it could be different with regards to financing. It could change for administration. But, in general terms, delegation (P1).

It would be very beneficial for devolution to lower units happen in our country if terrorism wasn't an issue. That's how it is. In word, I support devolution. However, if I take into consideration the current condition of our country, I find delegation more appropriate (P4).

"I am personally opposed to the idea of devolution. That's because, as I said, our country is a mosaic. Each region has its own local culture. We do not want it to cause division. This country has a flag, a border and an anthem, a symbol of independence. We want everyone to respect this, everyone to adopt and accept it. That is why we do not think that the devolution model would be very suitable for our country ... I think it would be more appropriate for deconcentration to take place. In other words, even in the case of the centralized administration, we are experiencing many difficulties. I think it would be more appropriate to appoint a commission because I don't think local governments would be experienced enough, and I think that experts with sufficient experience would make up the commissions $(P 2)$.

I support devolution when talking about decentralization in education. It needs to be autonomous (P6). 


\section{DISCUSSIONS and CONCLUSION}

Decentralization is regarded as being the transfer of authority from central government to local governments, and the majority of the participants regarded decentralization as highly autonomous being a type of devolution and autonomous in nature. Participants generally understood local governments as municipalities. In this context, it could be said that decentralization was understood as the transfer of schools to municipalities. This is usually perceived as dangerous in terms of the unitary (national) state structure, as decentralization is seen as more of a devolution to local governments. Actually, Papadopoulou and Yirci (2013) stated that Turkey was not ready for decentralization in education in terms of the present state of local governments, the acts, and geographical, cultural and social features. The underpinnings of the results of the both studies indicate that there are significant concerns about decentralization in education. Papadopoulou and Yirci (2013), in their same study, revealed some of the concerns as social inequalities, biased attitude in education, and undesired interventions of the society on educational management.

When opinions on decentralization in education were evaluated, it was observed that concerns were more expressed than positive opinions and expectations. Positive opinions of decentralization in education were mainly within the fields of finance, physical environment and infrastructure support, as well as organizational structure and administrative functioning. Regarding positive opinions in relation to organizational structure and administrative functioning, it was also stated most that bureaucracy would decrease, and as a result, tasks, decision-making and problem solving would accelerate. Taşar (2009) similarly concurs that bureaucracy will be decreased and decision-making will be faster thanks to decentralization. Moreover, it is noteworthy that the positive opinions regarding educational practices were not reported, indicating that the participants are of the opinion that decentralization in education does not contribute to education.

The general belief regarding decentralization in education was that local authorities could contribute to schools in the context of improving and financing the physical condition of schools. In line with this, expectations were that local governments could resolve financial and infrastructure problems. In their study, Papadopoulou and Yirci (2013) confirmed that educational decentralization could provide effective solutions for educational financing too. However, Ngok (2007), states that regional inequality in education in China has deteriorated because decentralization has stimulated the involvement of local governments and other non-state sectors in education development.

Regarding other aspects of the school system, decentralization was not widely embraced. It was stated that decentralization in education could be useful in the context of improving the physical structures, equipment and capacities of schools, so that principals would be able to allocate more time to education which is the main focus of education anyways. In fact, it could be said that this is one of the main reasons underlying the understanding of "limited decentralization run by central government" with regards to decentralization in education. For this reason, financial and limited administrative forms of decentralization were embraced. However, in a study conducted by Geçit (2008), the majority of the participants had expressed a centralized view that the central government should finance the school's financing of equipment. Moreover, it would be beneficial to be connected to a higher up in an administrative sense, which is completely opposed to autonomy altogether when talking about decentralization in education; however, from an administrative point of view, it was stated that more autonomy would be better than the current situation. From a political standpoint, it was emphasized that decentralization in education and nation-state and nationwide education should not be compromised. In addition, it was desirable that inspection practices be centralized, because there were concerns that localized inspections would increase political pressure and subjective application. In contrast, Turan, Yücel, Karataş and Demirhan (2010) found that inspectional authority must be run by the districts, which are the local units of central government.

Regarding concerns decentralization in education, there were strong deterrents related to educational politics as decentralizations could harm the nation-state structure. Participants believed that with decentralization in the education system, the curricula would be determined by local governments, thus separating itself from the national education system and damaging the nation-state structure. Therefore, it could be said that there were political concerns underneath the concerns regarding decentralization of the education system. In addition, it was determined that participants held the opinion that curricula needed to be common and national in terms of student mobility. It was emphasized that due to common 
curricula, it was possible for students to be able to relocate to schools in different provinces without any problems. Based on these views, it could be said that the general opinion of participants regarding educational policies and curricula was that the basic policies should be determined by central government in order to ensure that educational policies and curricula are national in nature. Only two participants emphasized that in addition to these considerations, it may need to have more flexibility to leave room for local governments. In short, it was desirable for the authorities in the centralized administration to continue in terms of educational policies and curricula. As a matter of fact, Hanson (1998) and Taşç (2008) point out that decentralization and curricula in education can move schools away from the national structure. Similar results have also emerged in studies conducted by KoçakUsluel (1997) and Geçit (2008) regarding the desirability of a centralized authority determining the curricula and the current centralized application to continue. However, in another study conducted by Bozan (2002), it had revealed that the authority of preparing the curriculum should be delegated to the national education directorates, which is the provincial units.

Participants were also concerned regarding the job security of the staff. As a result of the political pressure caused by the local governments, it was predicted that there would be an increase in favoritism and incapability in the schools, and it was expressed that the atmosphere of the workplace would deteriorate. For this reason, participants suggested that the authorities of central government continue with employing and relocating personnel. This conclusion also coincides with the study done by KoçakUsluel (1998) and Geçit (2008). Sawada and Ragatz (2005), however, take a different approach that decentralization may lead teachers showing more motivation. On the contrary, school principals stress their concerns about teacher performance and motivation in the present study. They think that decentralization will cause rises in favoritism, and mobbing in schools which then result in a decrease in motivation of teachers. In addition, there was an administrative concern as local governments were expected to exert political and administrative pressure on schools as well if decentralization in education was implemented. In a study conducted by Türkoğlu (2004), local administrators declared similar concerns. They emphasized that decentralization in education would cause a rise in power of local politics on education and lead to favoritism. In another study conducted by Addi-Raccah and Gavish (2010), the principals of the schools adopted school based management reported the power of local educational authorities over the schools was stronger than the schools not adopted school based management.

Kurt (2006) asserted that decentralization in education could assist in coping with the problems of the system. However, the participants of the present study indicated that this was not always possible. In order for the application of decentralization in education to be beneficial and effective, the participants desired that central government deal with the employment of personnel, protecting the individual rights of personnel and ensuring job security. It was also expected that the schools would be kept away from the political pressure of the local governments and that there would be no political enthusiasm found in them. This shows that participants have concerns about that decentralization may lead a rise in political pressure. If this is the case, Hannaway (1993) asserts that decentralization is far less likely to be successful in the environments with strong political pressures. Bardhan (2002) similarly emphasizes that indirect political pressures of local power elites may frustrate the goals of decentralization.

In addition, it was desired that for decentralization in education in our country to be successful for separatist terrorism to be finished off and schools to be connected to the policies decreed from the centralized authority. In particular, there should be an objective attitude based on qualifications displayed towards the employment, appointment, relocation and firing of personnel. There were opposing views as to whether or not the authority and responsibility of the employment and firing of personnel should be placed upon schools or the central government. However, the majority felt that the authority and responsibility should be placed on the central government. Similarly, in the studies done by Göksoy $(2014,2016)$, school administrators want to not have the authority to fire teachers and be completely autonomous, and that this authority should lie in the institutions in authority over the schools. However, in a study conducted by Turan et al. (2010), it was found that decision of employment and firing of personnel should be placed upon schools. West, Allmendinger, Nikolai and Barham (2010) reported test scores of students were high in the schools having autonomy over personnel management. In this sense, increasing the autonomy of schools on personnel management may be beneficial for Turkey, after the concerns in the present study were extinguished. 
Regarding suggestions related to funding, the physical environment and infrastructure support, suggestions were made that local governments should provide financial, physical and infrastructure support to schools, provide financial autonomy for schools, and build new schools to increase their number.

Within the scope of educational application, the suggestion was made that educational policies and curricula should be determined by central government, and that national curricula should be nationwide, though giving some place for flexibility. In the study of Turan et al. (2010), it was similarly revealed that the educational policies and curricula must be defined by the ministry.

In addition, it should be noted that suggestions were made that the internal inspection system should be evaluated according to objective criteria, that the inspection system should be based on central government, though stakeholders' opinions should be taken into account, that the inspection policy should be determined by the centralized administration, that higher education institutions or independent institutions should be able to do this and that schools should be inspected by local governments. This conclusion was also consistent with the study done by Taşç1 (2008). It was also stated that the inspection system should be centralized in order to ensure integrity and coherence with the education system.

When opinions regarding the different types of decentralization were evaluated, it became clear that an eclectic form of decentralization had emerged, in which different levels of decentralization in different areas of the education system were embraced. In fact, the eclectic model in which different forms of decentralization were preferred across different educational areas suggests that participants preferred decentralization, but because they are concerned about certain areas, they preferred to have a low level of decentralization in those areas or be completely dependent on the centralized administration. At the top of these concerns was the concern that the national structure of education would deteriorate and harm our nation state identity. It was also observed that there were some serious concerns regarding personnel employment, relocation and job security. On the whole, it was observed that there was a high level of concern regarding devolution in Turkey and also high concern for higher-level decentralization models. With this regard, it can be said that in the context of decentralization, a high level of autonomy was not embraced in every area of the education system.

In conclusion, from a holistic perspective, most of the participants found decentralization to be a very high form close to full autonomy. However, they wanted a low level of decentralization in the education system and they have more centralized attitudes towards educational processes except from financing and infrastructure support. This was indeed an indication that concerns related to decentralization in education are high. Some of the most serious of these concerns were (1) concerns regarding political pressure, (2) favoritism, (3) chaos in relocations and appointments, (4) deterioration of the national education structure, and (5) causing harm to the nation state structure. As a result, participants overwhelmingly believe that meritocracy based decentralization that will not harm our national identity and the national education structure can be useful and effective.

In this sense, policy makers should make the necessary regulations so that decentralization improves the education system. In this process, they had better take care of the concerns, expectations, and suggestions revealed in the present study.

In academic literature, there are so many studies on decentralization in education. In order to increase the efficiency of these studies and make them widespread throughout the community, the researchers may conduct meta-analysis studies in which holistic applicable suggestions were drawn especially for the policy makers, and administrators both in central and local governments.

\section{REFERENCES}

Addi-Raccah, A., \& Gavish, Y. (2010). The LEA's role in a decentralized school system: The school principals' view. Educational Management Administration \& Leadership, $38(2), \quad 184-201 . \quad$ DOI: $10.1177 / 1741143209356361$

Arslan, M. M., \& Atasayar, H. H. (2008). Ideas of the provincial managers of the Ministry of National Education about localization. Ankara University Journal of Faculty of Educational Sciences, 41 (2), 59-79.

Atasayar, H. H. (2005). Milli Ĕ̆itim Bakanlı̆̆ taşra örgütü yöneticilerinin yerelleşme konusundaki görüşleri (Yayımlanmamış Yüksek Lisans Tezi). Kırıkkale Üniversitesi Sosyal Bilimler Enstitüsü, Kırıkkale, Türkiye.

Balcı Bucak, E. (2000). Ĕgitimde yerelleşme. Ankara, Türkiye: Detay Yayınları.

Balcı, A. (2010). Açıklamalı ĕgitim yönetimi terimleri sözlüğü. Ankara, Türkiye: Pegem Akademi. 
Bardhan, P. (2002). Decentralization of governance and development. Journal of Economic perspectives, 16(4), 185-205.

Barrera-Osorio, F., Fasih, T., Patrinos, H. A., \& Santibáñez, L. (2009). Decentralized decision-making in schools: The theory and evidence on school-based management. Washington, USA: The World Bank.

Bozan, M. (2002). Merkeziyetçi yönetimden terinden yönetime geçişte alternatif yaklaşımlar: Milli Eğitim Bakanlı̆̆ı örneği (Yayımlanmamış Doktora Tezi). İnönü Üniversitesi Sosyal Bilimler Enstitüsü, Malatya, Türkiye.

Büyüköztürk, Ş., Çakmak, E. K., Akgün, Ö. E., Karadeniz, Ş., \& Demirel, F. (2010). Bilimsel araştırma yöntemleri. Ankara, Türkiye: Pegem Akademi.

Creswell, J. W. (2014). Research design: Qualitative, quantitative, and mixed methods approaches. Los Angeles, USA: Sage publications.

Dubois, H. F., \& Fattore, G. (2009). Definitions and typologies in public administration research: the case of decentralization. Intl Journal of Public Administration, 32(8), 704-727. DOI: $10.1080 / 01900690902908760$

Duman, A. (1998). Eğitimin yerinden yönetimi. [Local administration of education]. Çăgdaş Yerel Yönetimler Dergisi, 2, 83-93.

Erdem, A. R. (2016). Türk eğitim sisteminin yapısı. R. Sarpkaya (Ed.), Türk eğitim sistemi ve okul yönetimi (pp.3386). Ankara, Türkiye: Anı Yayıncılık.

Faguet, J. P., Fox, A. M., \& Poeschl, C. (2014). Does decentralization strengthen or weaken the state? Authority and social learning in a supple state. London, UK: Department of International Development, London School of Economics and Political Science.

Falleti, T. G. (2005). A sequential theory of decentralization: Latin American cases in comparative perspective. American Political Science Review, 99(3), 327-346.

Floresteal, K., \& Cooper, R. (1997). Decentralization of education: Legal issues. Washington, USA: The World Bank.

Geçit, Y. (2008). Eğitimde yerinden yönetim yaklaşımı (Yayımlanmamış Yüksek Lisans Tezi). Yeditepe Üniversitesi Sosyal Bilimler Enstitüsü, İstanbul, Türkiye.

Göksoy, S. (2014). To what extent should schools be autonomous? Educational Research and Reviews, 9(1), 2433. doi:10.5897/ERR2013.1679

Göksoy, S. (2016). How autonomous should schools be? Research based on teacher opinions. International Journal of Human Sciences, 13(1), 582-591. Doi:10.14687/ijhs.v13i1.3553

Güler, A., Halıcıoğlu, M. B, \& Taşğın, S. (2013). Sosyal bilimlerde nitel araştırma. Ankara: Seçkin.

Güran, M. C. (2001). Etkin devlet ve Türkiye. [Efficient State and Turkey]. H.Ü. Íktisadi ve Iddari Bilimler Fakültesi Dergisi, 19(1), 199-218.

Hannaway, J. (1993). Political pressure and decentralization in institutional organizations: The case of school districts. Sociology of Education, 66(3), 147-163.

Hanson, E. M. (1998). Strategies of educational decentralization: Key questions and core issue. Journal of Educational Administration, 36(2), 111-128. DOI:10.1108/09578239810204345

Hays, D. G., \& Singh, A. A. (2012). Qualitative inquiry in clinical and educational settings. New York, USA: Guilford Press.

İnce, M. (2009). Küreselleşme ve yerelleşme: Bir çelişki mi? [Globalization and localization: A contradiction?]. Gazi Üniversitesi İktisadi ve İdari Bilimler Fakültesi Dergisi, 11(1), 259-275.

Kaya, M. (2008). Okul merkezli yönetim sistemine ilişkin ögretmen görüşleri (Yayımlanmamış Yüksek Lisans Tezi). Yeditepe Üniversitesi Sosyal Bilimler Enstitüsü, İstanbul, Türkiye.

Kıran, H. (2001). Milli Eğitim Bakanlığı taşra örgütü yöneticilerinin eğitimde yerinden yönetime ilişkin tutumları. [The attitudes of provincial administrator of Ministry of National Education on local administration of education]. Pamukkale Üniversitesi Eğitim Fakültesi Dergisi, 9(9), 1-9.

Koçak-Usluel, Y. (1997). Milli Eğitim Bakanlığı'nın merkez örgütü yöneticilerinin yerelleşme konusundaki görüşleri. [The opinions of the central organization administrators of Ministry of National Education on the decentralization]. Ĕgitim ve Bilim, 21(103), 25-36.

Kurt, T. (2006). Eğitim yönetiminde yerelleşme eğilimi. [Decentralization Trend in Educational Administration]. Kastamonu Ĕ̌itim Dergisi, 14(1), 61-72.

Litvack, J. \& Seddon, J. (Eds.). (1999). Decentralization briefing notes. World Bank Institute WBI Working Papers in Collaboration with PREM Network. Retrieved from https://europa.eu/capacity4dev/file/8474/download?token=ViwoHuLP

Marques, J. F., \& McCall, C. (2005). The application of interrater reliability as a solidification instrument in a phenomenological study. The Qualitative Report, 10(3), 439-462.

Memduhoğlu, H. B. (2013). Türk eğitim sisteminin genel yapısı. H. B. Memduhoğlu, \& K. Yılmaz (Ed.), Türk eğitim sistemi ve okul yönetimi (pp.1-26). Ankara, Türkiye: PegemA. 
Mengi, A.\& Algan, N. (2003). Küreselleşme ve yerelleşme çağında bölgesel sürdürülebilir gelişme: AB ve Türkiye örneği. Ankara, Türkiye: Siyasal Kitabevi.

Milli Eğitim Bakanlığı. (2011). Milli Eğitim Bakanlığının teşkilat ve görevleri hakkında kanun hükmünde kararname [The executive order related to the organisation and duties of Ministry of National Education]. Resmi Gazete, Sayı: 28054.

Milli Eğitim Bakanlığı. (2015). Milli Ĕ̆itim Bakanlı̆̆ MEBBİS MEISS modülü. Retrieved from https://mebbis.meb.gov.tr

Mukundan, M. V., \& Bray, M. (2004). The decentralisation of education in Kerala State, India: Rhetoric and reality. International Review of Education, 50(3-4), 223-243.

Ngok, K. (2007). Chinese education policy in the context of decentralization and marketization: Evolution and implications. Asia Pacific Education Review, 8(1), 142-157.

Ökmen, M., \& Canan, K. (2009). Avrupa Birliği’ne üyelik sürecinde Türk kamu yönetimi. [The Turkish public administration in the process of adaptation to the EU]. Yönetim ve Ekonomi: Celal Bayar Üniversitesi Iktisadi ve İdari Bilimler Fakültesi Dergisi, 16(1), 139-171.

Ömür, Y. E. (2017). Eğitimde neoliberal yerelleşme ve eleştirisi. [Neoliberal decentralization in education and its critique]. Trakya Üniversitesi Ĕ̈itim Fakültesi Dergisi, 7(1), 10-25.

Özdemir, M. (2008). Eğitim yönetiminde yerelleşme siyasaları. [Decentralization policies in education administration]. Amme Idaresi Dergisi, 41(3), 153-168.

Özgen, V. (2011). Eğitim hizmetlerinde yerelleşme ve hizmet kalitesi (Yayımlanmamış Yüksek Lisans Tezi). Adnan Menderes Üniversitesi Sosyal Bilimler Enstitüsü, Aydın, Türkiye.

Özmüş, L. (2005, 28 Mart - 1 Nisan). Desantralizasyon (yerelleşme) ve yeni kamu yönetimi anlayışı. Paper presented at TMMOB Harita ve Kadastro Mühendisleri Odası 1. Türkiye Harita Bilimsel ve Teknik Kurultayı, Ankara, Türkiye. Retrieved from http://www.hkmo.org.tr/ resimler/ekler/SUO5_175_ek.pdf

Papadopoulou, V., \& Yirci, R. (2013). Rethinking decentralization in education in terms of administrative problems. Educational Process: International Journal, 2(1-2), 7-18.

Prud'homme, R. (1995). The dangers of decentralization. The World Bank Research Observer, 10(2), 201-220.

Rondinelli, D. A., Nellis, J. R., \& Cheema, G. S. (1983). Decentralization in developing countries. World bank staff working paper, 581. Washington, USA: The World Bank.

Sağlam, A. Ç. (2010). Yönetimde yerelleşme. H. B. Memduhoğlu, \& K. Yılmaz (Ed.), Yönetimde yeni yaklaşımlar (pp.97-109). Ankara, Türkiye: PegemA.

Satria, A., \& Matsuda, Y. (2004). Decentralization of fisheries management in Indonesia. Marine Policy, 28(5), 437-450.

Sawada, Y., \& Ragatz, A. B. (2005). Decentralization of education, teacher behavior, and outcomes. In E. Vegas (Ed.), Incentives to improve teaching (pp. 255-306). Washington, DC: The World Bank.

Schneider, A. (2003). Decentralization: Conceptualization and measurement. Studies in comparative international development, $38(3), 32-56$.

Sharma, C. (2006). Decentralization dilemma: Measuring the degree and evaluating the outcomes. The Indian Journal of Political Science, 67(1), 49-64.

Taşçı, H. (2008). Yerel yöneticiler ve okul yöneticilerinin eğitimde yerelleşmeye ilişkin kendilerini hazır görme durumları (Yayımlanmamış Yüksek Lisans Tezi). Çanakkale Onsekiz Mart Üniversitesi Sosyal Bilimler Enstitüsü, Çanakkale, Türkiye.

Taşar, H. H. (2009). Merkeziyetçi yönetim yapısının kamu okulları üzerinde bıraktı̆ğ olumsuz etkiler. [Negative affects of centralist administration approach on public schools]. Adiyaman Üniversitesi Sosyal Bilimler Enstitüsü Dergisi, 2(2), 108-119.

The World Bank. (2013, June). Types of decentralization. In Decentralization. Retrieved from http://www.worldbank.org/en/topic/communitydrivendevelopment/brief/Decentralization

Turan, S., Yücel, C., Karataş, E., \& Demirhan, G. (2010). Okul müdürlerinin yerinden yönetim hakkındaki görüşleri [Opinions of school principals about local management]. Uşak Üniversitesi Sosyal Bilimler Dergisi, 3/1, 1-18.

Türkoğlu, R. (2004). Eğitimde yerelleşme sorununa kamu yönetimi temel kanunu tasarısı ve yerel yönetim yasa tasarısının getirdiği çözümler konusunda yerel yöneticilerin görüşleri. Inönü Üniversitesi Eğitim Fakültesi Dergisi. 5(8).

Uz, M. (2009). Illköğretim okulu müdürlerinin okul merkezli yönetimin bütçe boyutuna ilişkin görüşleri (Yayımlanmamış Yüksek Lisans Tezi). Çanakkale Onsekiz Mart Üniversitesi Sosyal Bilimler Enstitüsü, Çanakkale, Türkiye.

Uzun, F. (2015). Türkiye'de yerel yönetimlerin eğitim harcamalarındaki rolü ve etkileri (Yayımlanmamış Doktora Tezi). Hacettepe Üniversitesi Eğitim Bilimleri Enstitüsü, Ankara, Türkiye.

West, A., Allmendinger, J., Nikolai, R., \& Barham, E. (2010). Decentralisation and educational achievement in Germany and the UK. Environment and Planning C: Government and Policy, 28(3), 450-468. DOI:10.1068/c0992 
World Development Report (WDR). (2017). Governance and law. Washington, USA: The World Bank Group. Retrieved from https://openknowledge.worldbank.org/bitstream/handle/10986/ 25880/9781464809507.pdf

Yavuz, Y. (2001). Lise yöneticilerinin ve ögretmenlerinin okulda yerinden yönetim ve merkezden yönetim yaklaşımlarına ilişkin görüşlerinin karar verme sürecine etkileri (Yayımlanmamış Doktora Tezi). Dokuz Eylül Üniversitesi Eğitim Bilimleri Enstitüsü, İzmir, Türkiye.

Yin, R. K. (2011). Qualitative research from start to finish. New York, USA: The Guilford Press.

Yıldırım, A., \& Şimşek, H. (2011). Sosyal bilimlerde nitel araştırma yöntemleri. Ankara, Türkiye: Seçkin Yayınevi.

Yolcu, H. (2010). Neo-liberal dönüşümün yaşandığı ülkelerde yerelleşme ve okul özerkliği uygulamaları. [Decentralization and school autonomy practices in countries experiencing neo-liberal transformation]. ZKÜ Sosyal Bilimler Dergisi, 6(12), 253-273

Yuliani, E. L. (2004, 27-30 April). Decentralization, deconcentration and devolution: What do they mean? Interlaken Workshop on Decentralization. Interlaken, Switzerland. Retrieved from http://www.cifor.org/publications/pdf_files/interlaken/Compilation.pdf 


\section{TÜRKÇE GENIŞLETILMIŞ ÖZET}

Yerelleşme merkezi yönetimin bazı konularda ve durumlarda var olan yetkilerini daha alt yerel birimlere devretmesi şeklinde tanımlanmaktadır. Aynı zamanda, yerelleşme, karar yetki ve görevlerin işi bizzat yapanlara devrini ifade etmektedir. Başka bir ifadeyle, kamusal faaliyetlere ilişkin merkezi yönetimin yetki ve sorumluluklarının taşra birimlerine, yerel yönetimlere, yarı özerk kamu kurumlarına veya özel sektöre devredilmesi olarak belirtilmektedir (Atasayar, 2005; Balc1, 2010; Litvack ve Seddon, 1999; Özmüş, 2005; Sağlam, 2010; Uz, 2009; Yuliani, 2004). Yerelleşmeye ilişkin bakış açılarındaki çeşitlilikten ve yerelleşmeye yüklenen anlamdan dolayı görevlendirme, yetki devretme, yetki aktarma ve özelleştirme şeklinde farklı yerelleşme model ve biçimleri bulunmaktadır (Arslan \& Atasayar, 2008; Balc1, 2010; Florestal \& Cooper, 1997; Hanson, 1998; Koçak-Usluel, 1997; Ömür, 2017; Özdemir, 2008; Özmüş, 2005; Sağlam, 2010; Yuliani, 2004).

Görevlendirme merkezden taşra örgütüne yetki devridir. Aynı zamanda görevlendirme merkezin, bir takım bürokratik işlerini uç noktalardaki taşra teşkilatları eliyle yürütmesidir. Burada herhangi bir siyasi yetki devri söz konusu değildir. Bu nedenle, görevlendirme yerelleşmenin en hafif şekli olarak kabul edilmektedir (Balc1, 2010; Duman, 1998; Koçak-Usluel, 1997; Özmüş, 2005; Yolcu, 2010; Yuliani, 2004).

Yetki devretme, merkezi yönetimin görevlerinin özerk örgütlere devri olarak tanımlanabilir. Yetki devretme, görevlendirmeye göre bir üst yerelleşme biçimidir. Yetki devretme ile merkezi yönetimler karar verme ve sorumluluk yetkilerini yarı otonom kurumlara devretmiş olurlar. Bu kurumlar tamamen kontrol altında tutulamaz, merkez hükümet tarafından dolaylı olarak denetlenirler. Nihai sorumluluk yine merkezi yönetimde kalmak koşuluyla tanımlanmış fonksiyonlarını yerine getirmek üzere tüm yetkiler ve işler yerel örgütlere devredilir (Balc1, 2010; Florestal \& Cooper, 1997; Koçak-Usluel, 1997; Özmüş, 2005).

Yetki aktarma yerinden yönetim olarak da bilinmektedir. Yetki aktarmada özerk ve bağımsız, gelir toplama ve harcama yetkisi olan ulus altı birimlerin oluşturulması söz konusudur. Başka bir deyişle yetki aktarma ile milli yapılanmanın altında özerk alt düzey bir yapılanma oluşturulmaktır. Oluşturulan bu alt düzey yapılanmanın coğrafi sınırları iyice çizilmiş, yasal durumu net olarak tanımlanmış, gelir elde edebilen ve harcayabilen duruma gelmiştir. Yetki aktarmada yerel yönetimler sadece idari fonksiyonları değil aynı zamanda yetkileri ve sorumlulukları da devralır. Ancak, yine de tam olarak özerk bir yapıya kavuşmuş değillerdir (Balcı, 2010; Barrera-Osorio, Fasih, Patrinos, \& Santibáñez, 2009; Florestal \& Cooper, 1997; Hanson, 1998; Koçak-Usluel, 1997; Özmüş, 2005; Yuliani, 2004).

Özelleştirme ise yerelleşmenin en üst düzey biçimi olarak kabul edilmekte olup karar alma yetkisi kamudan özel sektöre verilmektedir (Balc1, 2010; Florestal \& Cooper, 1997; Özmüş, 2005).

Yerelleşme, hizmetlerin topluma en yakın birimlerce yürütülmesinde, hizmet alanların memnuniyetlerinin artırılmasında, hizmette etkililik ve verimliliğin sağlanmasında etkili bir araç niteliğindedir. Ancak, asıl önemli olan, yerelleşmenin topluma ve devlet yapısına uygun bir şekilde tasarlanması ve uygulamaya konulmasıdır. Çalışmada yöneticilerin eğitimde yerelleşmeye ilişkin tutumları hem beklenti hem de kaygıları bağlamında derinlemesine incelenmiş olup, nihai düzeyde ön görülen yerelleşme modelleri eğitim süreçleri bağlamında hem ayrı hem de bütünsel düzeyde tespit edilmiştir. $\mathrm{Bu}$ açıdan çalışma eğitimde yerelleşme uygulamasının hayata geçirilebilmesi bağlamında politika yapıcılara ve uygulayıcılara sistem tasarımı açısından katkı sağlayıcı niteliktedir. Nitekim, kaygıların giderildiği, beklentilerin gerçekleştiği ve önerilerin dikkate alındığı yerelleşme uygulaması iyi işleyen bir eğitim sistemi açısından faydalı olacaktır. Bu noktadan hareketle çalışmanın amacı, ilkokul ve ortaokul müdürlerinin eğimde yerelleşmeye ilişkin görüşlerini belirlemektir.

Çalışmada nitel araştırma yöntemlerinden olgu bilim çalışması deseni kullanmıştır (Creswell, 2014; Fraenkel, Wallen \& Hyun, 2011). Çalışma grubu, kamu okullarında çalışan, eğitim yönetimi konusunda eğitim almış, ilkokul ve ortaokul düzeyinde en az beş yıl yöneticilik deneyimine sahip altı ilköğretim kurumu müdüründen oluşmaktadır. Çalışma grubu belirlenirken amaçlı örnekleme yöntemlerinden ölçüt örnekleme ve kolay ulaşılabilir durum örneklemesi kullanılmıştır. Ayrıca, katılımcıların araştırmaya katılmada gönüllü olmaları esas alınmıştır. Araştırmacı tarafından okul müdürleriyle bireysel yüz yüze görüşmeler yapılmıştır. Görüşmeler okullarda katılımcıların odalarında gerçekleştirilmiştir. Veri toplama aracı olarak araştırmacı tarafından hazırlanan yarı yapılandırılmış görüşme formu kullanılmıştır. Verilerin analizinde NVIVO nitel araştırma programından yararlanılarak hem betimsel analiz hem de tümevarımsal içerik analizi yapılmıştır. 
Sonuç olarak, yerelleşme genellikle, merkezi yönetimin yetkilerinin yerel yönetimlere devredilmesi olarak algılanmakta olup katılımcıların çoğunluğu yerelleşmeyi üst düzey özerkliğin olduğu yetki aktarma ve üzerindeki daha özerk yerelleşme biçimleri olarak kabul etmektedir. Aslında katılımcıların çoğunluğunun yerelleşmeyi üst noktada gördükleri, tam özerkliğe yakın buldukları söylenebilir. Ancak eğitim sisteminin yerelleşmesine ilişkin düşünceleri sorulduğunda yerelleşme düzeyi algıların düşük olduğu, finansman ve altyapı desteği dışında daha merkeziyetçi tutum sergiledikleri görülmektedir. $\mathrm{Bu}$ durum aslında eğitimde yerelleşmeye ilişkin kaygıların yüksek olduğunun bir göstergesidir. $\mathrm{Bu}$ kaygıların en önemlilerinden bazıları (1) siyasi baskı kaynaklı işten atılma kaygısı, (2) kayırmacı1ık, (3) nakil ve tayinlerde karmaşa, (4) eğitimin milli yapısının bozulacağı ve (5) ulus devlet yapısının zarar göreceği endişeleridir.

Eğitimde yerelleşmeye ilişkin olumlu görüşler ise genellikle, finansman, fiziki ortam ve alt yapı desteği ile örgütsel yap1 ve yönetsel işleyiş alanındadır. Eğitsel uygulamalara ilişkin olumlu görüş bildirilmemesi ise dikkat çekici bir durum olup katılımcıların eğitimde yerelleşmenin eğitsel açıdan katkı sağlayıcı nitelikte olmadığına dair düşünce içerisinde olduklarını göstermektedir.

Eğitimde yerelleşmenin uygulanması halinde yararlı ve etkili olabilmesi için personel istihdamının merkezi yönetimler tarafından yapılması, personelin özlük haklarının korunması ve iş güvencesinin sağlanması arzu edilmektedir. Ayrıca eğitim kurumlarının yerel yönetimlerin siyasi baskılarından uzak tutulması ve siyasi kayırmacılığın olmaması da beklentiler arasında yer almaktadır. Bunların yanı sıra ülkemizde eğitimde yerelleşmenin başarılı olabilmesi için ayrılıkçı terörün bitirilmesi ve okulların temel politikalar bağlamında merkeze bağlı olması arzu edilmektedir. Özellikle istihdam, atama, tayin ve işten çıkarmada liyakat esaslı objektif tutum sergilenmesi gerektiği belirtilmektedir. Personel istihdamının ve işten çıkarmanın yetki ve sorumluluğunun okullarda ve merkezi yönetimde olması gerektiğine dair karşıt düşünceler bulunmaktadır. Ancak merkezi yönetimin bu yetki ve sorumluluğu devam ettirmesi yönündeki görüşler ağır basmaktadır.

Özetle, eğitimde yerelleşmeye ilişkin görüşler değerlendirildiğinde olumlu görüşler ile beklentilere nazaran genellikle kaygıların ifade edildiği görülmektedir. Eğitimde yerelleşmeye ilişkin genel kanı okulların fiziki şartlarının iyileştirilmesi ve finansmanı bağlamında okullara yerel yönetimler tarafından katk1 sağlanılması yönündedir. Beklentiler, okullara yerel yönetimlerin maddi kaynak sağlaması ve alt yapı sorunlarını çözmesi noktasında yoğunlaşmaktadır. Okul sisteminin diğer boyutları açısından ise yerelleşme çok benimsenmemektedir. Son olarak katılımcilarda personel rejimi hususunda liyakatin temel alındığı, ulus devlet kimliğimize ve eğitimin milli yapısına zarar vermeyecek bir yerelleşme anlayışının hâkim olduğu söylenebilir. 